\title{
O gênero Paspalum L. (Poaceae) na Chapada Diamantina, Bahia, Brasil'
}

\author{
Karena M. Pimenta ${ }^{2}$ (D), Gabriel H. Rua ${ }^{3,4}$ (1) \& Reyjane P. Oliveira ${ }^{2}$
}

\author{
'Parte da dissertação de Mestrado da primeira autora no Programa de Pós-Graduação em \\ Botânica da Universidade Estadual de Feira de Santana \\ ${ }^{2}$ Universidade Estadual de Feira de Santana, Departamento de Ciências Biológicas, Programa de Pós-graduação em Botânica, \\ BR 116 N km 3, CEP 44031-460, Feira de Santana, Bahia, Brasil. karenamendes@hotmail.com \\ ${ }^{3}$ Universidad de Buenos Aires, Facultad de Agronomía, Cátedra de Botánica Sistemática, Avenida San Martín 4453, C1417DSE، \\ Buenos Aires, Argentina. \\ ${ }^{4}$ Consejo Nacional de Investigaciones Científicas y Técnicas, Buenos Aires, Argentina
}

Recebido em 05.III.2018

Aceito em 19.VIII.2019

DOI 10.21826/2446-82312019v74e2019011

RESUMO - No presente estudo foi realizado o levantamento das espécies de Paspalum ocorrentes na região setentrional da Cadeia do Espinhaço, a região da Chapada Diamantina, localizada no centro do estado da Bahia, com base em coletas próprias e materiais depositados nos principais herbários do Brasil. Foram encontradas 40 espécies, duas delas representando novos registros para a Bahia (P. erianthum Nees ex Trin. e P. robustum (Hitchc. $\&$ Chase) S. Denham) e três são novos registros para o Nordeste (P. mandiocanum var. subaequiglume Barreto, P. plenum Chase e P. trichostomum Hack.). Uma chave de identificação para as espécies de Paspalum encontradas na área, descrições e ilustrações são fornecidas.

Palavras chave: Cadeia do Espinhaço, florística, Gramineae

\begin{abstract}
Genus Paspalum L. (Poaceae) at Chapada Diamantina, Bahia, Brazil. A floristic survey of the species of Paspalum from the Chapada Diamantina, Northern portion of the Espinhaço Range, in the central region of the state of Bahia, was carried out, based on our collections, as well as specimens housed in the main Brazilian herbaria. Forty species were found, including two new records for Bahia ( $P$. erianthum and $P$. robustum) and three new records for Northeastern Brazil (P. mandiocanum var. subaequiglume, P. plenum and P. trichostomum). An identification key to the species of Paspalum found in the area, descriptions, and illustrations are provided.
\end{abstract}

Keywords: Espinhaço Range, floristic, Gramineae

\section{INTRODUÇÃO}

Paspalum L. representa um dos maiores gêneros de Poaceae. Inserido na tribo Paspaleae, ocupa lugar de destaque na subtribo Paspalinae (Morrone et al. 2012), incluindo de 310 (Morrone et al. 2012) a 350 espécies, as quais habitam diversos ambientes ao longo do continente Americano, além de registros para África, Ásia e Oceania (Rua et al. 2010). O gênero possui grande importância econômica, com muitas espécies consideradas excelentes forrageiras, a exemplo de $P$. notatum Flüggé e $P$. dilatatum Poir. (Allem \& Valls 1987).

Segundo dados da Flora do Brasil 2020 são indicadas 214 espécies de Paspalum ocorrentes no país, 68 delas registradas para a Bahia. Como os estudos florísticos e taxonômicos envolvendo Paspalum no Brasil têm sido mais concentrados nas regiões Sul e Centro-Oeste, as informações acerca do mesmo no Nordeste ainda são escassas. Isso inclui as áreas pertencentes à Cadeia do Espinhaço, na qual a região da Chapada Diamantina tem sido considerada uma região de extrema importância biológica (Rocha et al. 2005).

Devido ao elevado número de espécies, marcada variabilidade morfológica do grupo, importância econômica e ecológica (Chase 1929; Zuloaga \& Morrone 2005), este trabalho teve como principal objetivo realizar o levantamento do gênero Paspalum na região da Chapada Diamantina; identificar, descrever e ilustrar as espécies ocorrentes na área, fornecendo meios para sua identificação; além de disponibilizar dados sobre os ambientes de ocorrência das espécies; a fim de contribuir tanto para ampliar o conhecimento sobre a família Poaceae na Chapada Diamantina, quanto sobre Paspalum no Nordeste.

\section{MATERIAL E MÉTODOS}

A região da Chapada Diamantina está localizada na região central da Bahia, na porção setentrional da Cadeia do Espinhaço (Fig. 1), um dos principais conjuntos montanhosos do leste do Brasil, que se estende da Bahia até Minas Gerais (Giulietti et al. 1996). Compreendendo 


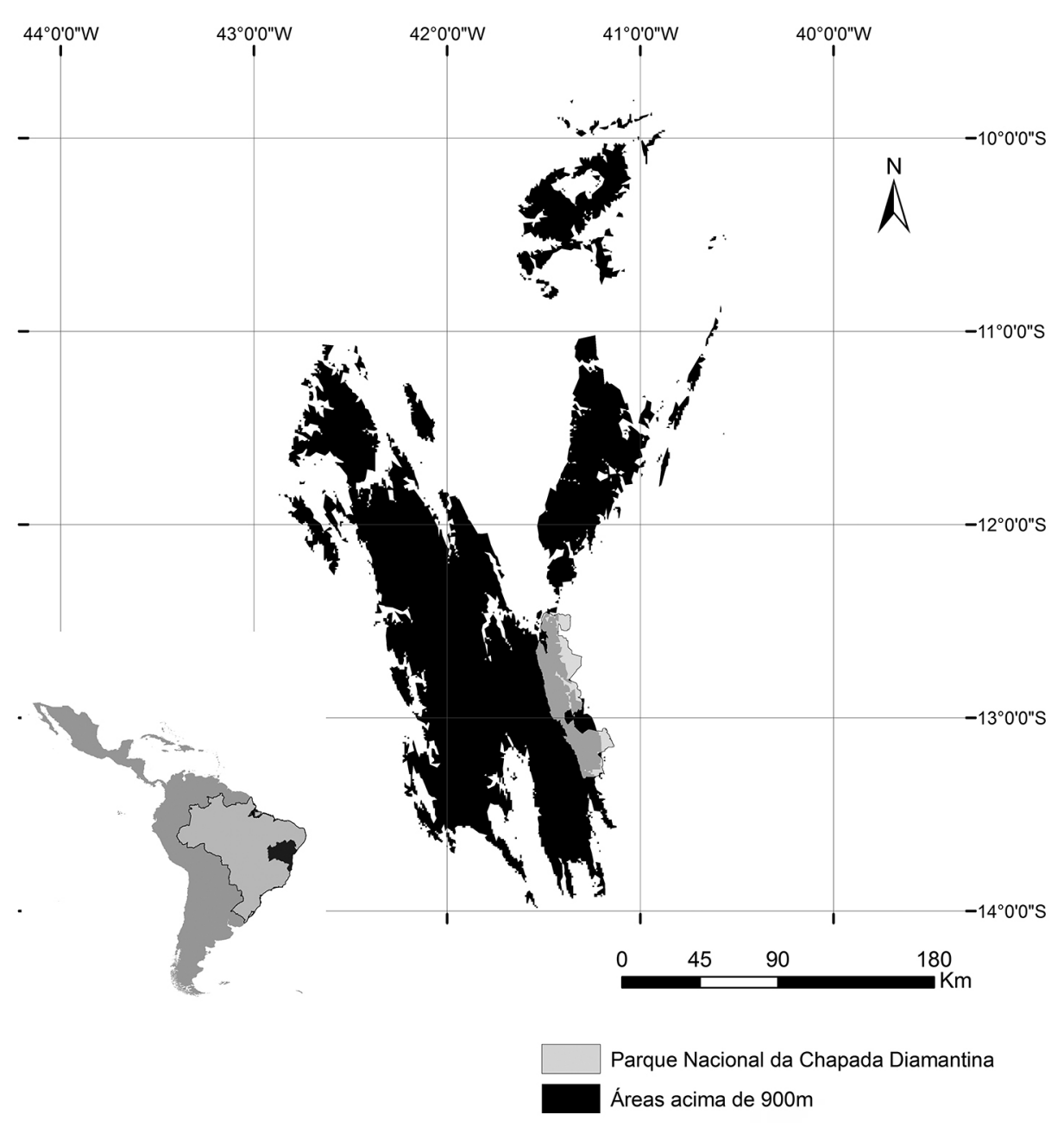

Fig. 1. Mapa da região da Chapada Diamantina, Bahia, Brasil.

uma área de $41.994 \mathrm{~km}^{2}$ (CAR 1995), a região é formada por terrenos baixos e elevações acima de $1000 \mathrm{~m}$ de altitude (Pirani et al. 2003). A heterogeneidade de substrato, topografia e microclima são refletidas na estrutura das comunidades e na composição florística, agregando vários microambientes em espaços restritos (Conceição \& Giulietti 2002; Vitta 2002; Conceição \& Pirani 2005; Conceição et al. 2005), gerando um mosaico de vegetações que inclui campos rupestres, cerrados, florestas e caatingas (Rocha et al. 2005).

A cobertura vegetacional mais característica da Chapada Diamantina, assim como em toda a Cadeia do Espinhaço, é o campo rupestre, que ocupa altitudes acima de $900 \mathrm{~m}$ (Giulietti et. al. 1987), composto principalmente pelas famílias Asteraceae, Bromeliaceae, Cactaceae, Eriocaulaceae, Orchidaceae, Poaceae, Velloziaceae e Xyridaceae (Andrade et al. 1986; Giulietti et al.1987; Harley 1995; Rapini et al. 2008).

Foram realizadas sete expedições à regiões da Chapada Diamantina que possuíam poucos registros de amostras de Paspalum em herbário, sendo visitados os principais tipos vegetacionais, incluindo cerrados, campos rupestres, florestas e caatingas (Fig. 2). Sempre que possível, os materiais foram fotografados em campo e herborizados segundo métodos tradicionais em taxonomia (Mori et al. 1989). As exsicatas foram depositadas no Herbário da Universidade Estadual de Feira de Santana (HUEFS), com duplicatas para o CEPEC e ALCB, além do BAA, na Argentina (siglas segundo Thiers 2019).

Foram consultados bancos de dados on-line dos principais herbários do Brasil (SpeciesLink e Herbario Virtual do Reflora, e do exterior, incluindo Grass Catalogue (Missouri Botanical Garden), GrassBase (Royal Botanic Gardens, Kew) e Global Plants (JSTOR). Os seguintes herbários do Brasil foram visitados: ALCB, CEN, CEPEC, HUEFS, RB, SP, SPF, UB e UESC. A identificação dos materiais foi baseada nas descrições originais das espécies, materiais-tipo e demais bibliografias especializadas. As ilustrações foram confeccionadas com auxílio de câmara clara, e finalizadas com a técnica nanquim em papel. O mapa da área de estudo foi confeccionado por meio do software ArcGis (ESRI 2010). 

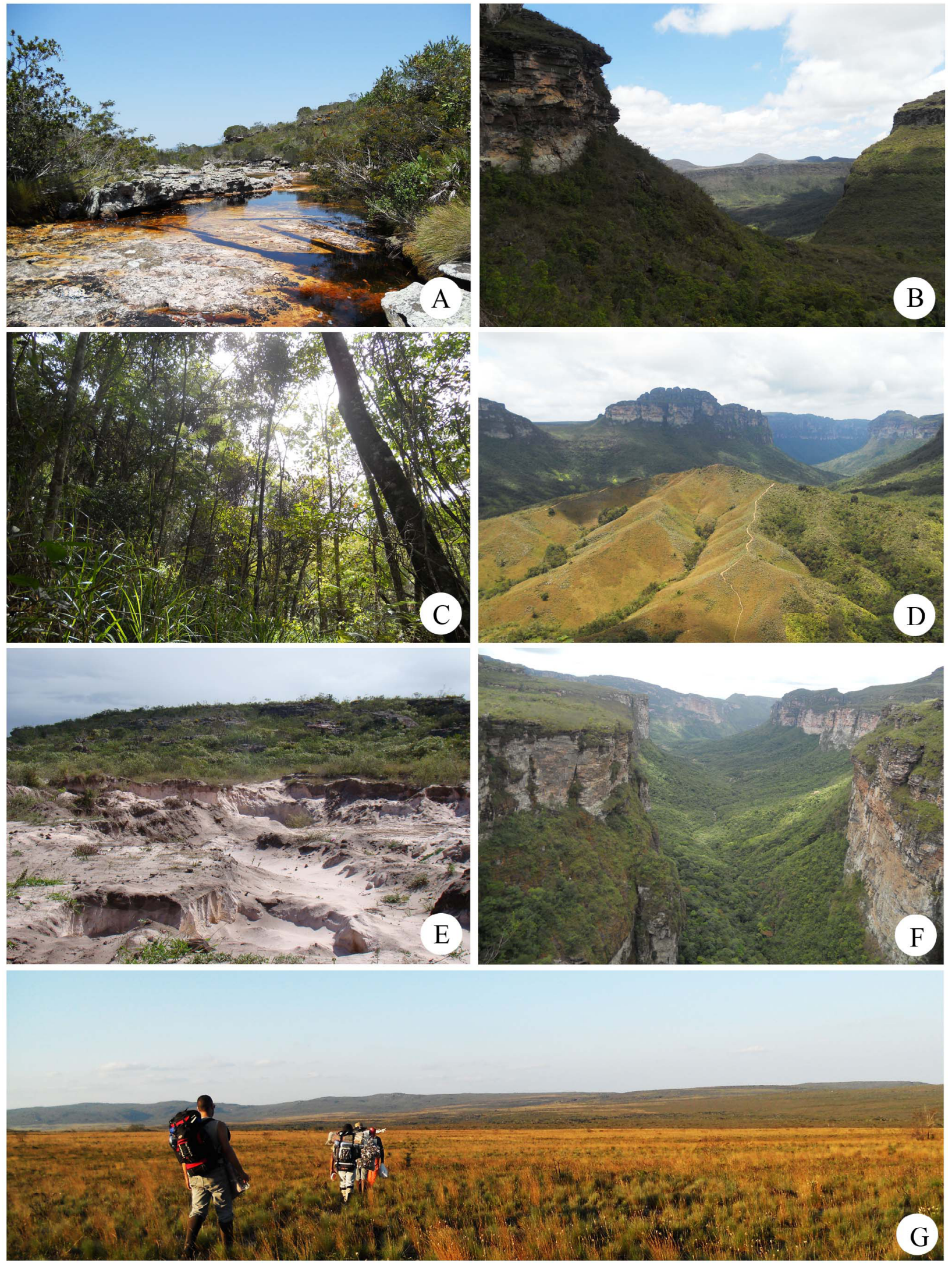

Figs. 2A-G. A. Campo rupestre, Ibicoara; B. Vista do Morro Castelo, Ibicoara; C. Mata de Galeria, trilha Vale do Pati, Ibicoara; D. Vista do Mirante, Vale do Pati, Mucugê; E. Dunas de Morro do Chapéu; F. Cachoeira do Buracão vista de cima, trilha Vale do Pati; G. Gerais do Machombongo, Ibicoara. Fotos (K.M. Pimenta). 


\section{RESULTADOS E DISCUSSÃO}

Foram coletados 123 espécimes de Paspalum e consultadas 253 exsicatas, totalizando 376 amostras analizadas. Foi constatada a ocorrência de 40 espécies de Paspalum na Chapada Diamantina, duas das quais representam novos registros para a Bahia (P. erianthum Nees ex Trin. e P. robustum (Hitchc. \& Chase) S. Denham, e três são novos registros para o Nordeste (P. mandiocanum Trin. var. subaequiglume, $P$. plenum Chase e $P$. trichostomum Hack.). Uma nova espécie foi recentemente descrita, cujo status foi confirmado durante as coletas realizadas como parte do presente levantamento (P. giuliettiae K.M. Pimenta, G.H. Rua \& R.P. Oliveira). Além destas, o morfotipo aqui tratado como Paspalum sp., não se enquadra em nenhuma das espécies conhecidas do gênero até o momento, mas a mostragem ainda é insuficiente para a proposição de um novo táxon. As formações vegetacionais que apresentaram as maiores concentrações de espécies foram o campo rupestre (15 espécies) e a caatinga (14 espécies).

Paspalum L., Syst. Nat., ed. 10. 2: 855. 1759.

Plantas anuais ou perenes; cespitosas, decumbentes ou estoloníferas. Colmos invaginados ou não, com poucos ou muitos nós. Folhas concentradas na base da planta ou distribuídas ao longo do colmo; bainhas infladas ou não, desfiadas na base ou não, glabras a híspidas; lígula membranosa; aurículas ausentes ou raramente presentes; lâminas lanceoladas, lineares ou filiformes, planas, conduplicadas ou convolutas, ápice geralmente agudo, base arredondada, truncada ou atenuada, glabras a pilosas, margens hialinas, glabras a escabras. Inflorescências terminais com 1-muitos ramos unilaterais solitários, alternos, conjugados ou subconjugados; inflorescências axilares presentes ou ausentes; ráquis tríquetro a dorsiventral, com ou sem expansões laterais formando alas membranáceas. Espiguetas com 2 antécios, acrótonas, solitárias ou pareadas, pediceladas, raramente sésseis, planoconvexas ou côncavo-convexas, elípticas, lanceoladas, ovais, obovais, oblongas, orbiculares ou escutadas, agudas ou obtusas, apiculadas ou não, castanhas, castanho-claras, esverdeadas, ferrugíneas, paleáceas ou vináceas; gluma inferior geralmente ausente; gluma superior geralmente presente, adaxial à ráquis, 2-9-nervada, glabra, pilosa ou vilosa, raramente papilosa; tricomas tuberculados, clavados, adpressos, globulares, velutinos, simples, longos ou curtos; lema inferior 2-5-nervado, com ou sem manchas, raramente hialino ou papiloso, glabro ou piloso; tricomas tuberculados, clavados, adpressos, globulares, velutinos, simples, longos ou curtos, margens glabras a ciliadas; antécio inferior estéril ou raramente estaminado, pálea presente ou ausente; antécio superior com flor bissexuada, linear, elíptico, oval, oboval, orbicular, suborbicular, oblanceolado ou oblongo, ápice agudo ou obtuso, glabro, raramente piloso, liso a papiloso, estramíneo, castanho ou castanho escuro, raramente estipitado. Cariopse oval, oboval, suborbicular, orbicular, elíptica, verde, castanha ou estramínea.

Algumas espécies do gênero Paspalum podem ser consideradas cosmopolitas, porém a grande maioria é restrita ao continente Americano, e provavelmente o gênero tenha se originado na região tropical da América do Sul (Rua et al. 2010). A chave a seguir indica os principais caracteres usados para separar as espécies de Paspalum ocorrentes na Chapada Diamantina.

\section{Chave para as espécies de Paspalum L. da Chapada Diamantina, Bahia, Brasil}

1. Antécio superior castanho escuro quando maduro.

2. Plantas anuais; bainhas glabras; lâminas foliares 2,5-9 cm compr., lanceoladas, planas, glabras, base truncada; espiguetas $1,9-2 \mathrm{~mm}$ compr.

19. P. melanospermum

2'. Plantas perenes; bainhas pilosas; lâminas foliares 10,5-18 cm compr., lineares, conduplicadas, hirsutas, base atenuada; espiguetas com 2,5-3,5 mm compr.

3. Plantas cespitosas; lígula 1,5-2 mm compr.; lema inferior hialino no centro

35. P. rojasii

3'. Plantas estoloníferas; lígula 2,5-3,5 mm compr.; lema inferior hialino em toda a extensão ....... 40. Paspalum sp.

1 '. Antécio superior estramíneo quando maduro.

4. Inflorescência com 2 ramos conjugados ou subconjugados.

5. Plantas estoloníferas ou rizomatosas. Espiguetas sempre solitárias.

6. Plantas rizomatosas; lâminas foliares filiformes; espiguetas 2,2-2,5 mm compr.; gluma superior papilosa, geralmente com máculas, não ciliada nas margens .....

16. P. maculosum

6'. Plantas estoloníferas; lâminas foliares lanceoladas; espiguetas 1,5-1,7 mm compr.; gluma superior não papilosa, sem máculas, longamente ciliada nas margens 5. $P$. conjugatum

5'. Plantas cespitosas. Espiguetas solitárias ou pareadas.

7. Plantas anuais; espiguetas pilosas, 1-1,2 mm compr., solitárias ou pareadas.

8. Inflorescência com ramos subconjugados; espiguetas pareadas, obovadas, com tricomas clavados

8'. Inflorescência com ramos conjugados; espiguetas solitárias, orbiculares, com tricomas globulares 
7'. Plantas perenes; espiguetas glabras (às vezes com uns poucos tricomas na base da espigueta em $P$. lineare), 1,5-6 mm compr., sempre solitárias.

9. Lâminas foliares filiformes; espiguetas 3-6 mm compr.

14. P. lineare

9'. Lâminas foliares planas; espiguetas 1,5-2,2 mm compr.

10. Inflorescências terminais e axilares; antécio superior com ápice arredondado

10. P. giuliettiae

$10^{\prime}$. Inflorescências apenas terminais; antécio superior com ápice obtuso 32. P. pumilum

4'. Inflorescências com 1-numerosos ramos alternos ou subdigitados, nunca 2 conjugados.

11. Espiguetas solitárias.

12. Plantas aquáticas, flutuantes; bainhas infladas; aurículas presentes; inflorescências com 30-54 ramos 33. P. repens

12'. Plantas terrestres, cespitosas; bainhas não infladas; aurículas ausentes; inflorescências com até 11 ramos.

13. Espiguetas pilosas.

14. Ráquis alada; espiguetas longamente pilosas na porção inferior; lema do antécio superior não envolvendo o ápice da pálea.

15. Racemos 8-11, subdigitados; ráquis 4-7 mm larg.; espiguetas 5-7 mm compr., com ápice acuminado; antécio superior estipitado

12. P. lanciflorum

15'. Racemos 1-2, alternos; Ráquis até 3,5 mm larg.; espiguetas 3-5 mm compr., com ápice agudo ou arredondado; antécio superior não estipitado.

3. P. carinatum

14'. Ráquis não alada; espiguetas uniformemente pilosas; lema do antécio superior envolvendo o ápice da pálea

1. P. ammodes

13'. Espiguetas glabras.

16. Plantas cespitosas; folhas pilosas ou glabras, concentradas na base dos colmos; ramos das inflorescências alternos; espiguetas até $2 \mathrm{~mm}$ compr.

17. Espiguetas 1,8-1,9 mm compr.; plantas perenes.

18. Folhas glabras. Inflorescências terminais e axilares; antécio superior 1-1,2 mm larg

18'. Folhas pilosas. Inflorescências apenas terminais; antécio superior 0,8-0,9 mm larg.

19. Lema com uma porção hialina no centro

10. P. giuliettiae

19 '. Lema inferior não hialina, com uma mancha em forma de $\mathrm{V}$

11. P. hyalinum

17 '. Espiguetas 0,6-0,7 mm compr.; plantas anuais

21. P. minarum

16'. Plantas rizomatosas; folhas sempre glabras, distribuídas ao longo dos colmos; ramos das inflorescêncis subdigitados; espiguetas 2,2-2,5 mm compr.

17. P. madorense

11'. Espiguetas pareadas (em P. robustum aparentemente solitárias por concrescência com a Ráquis).

20. Plantas geralmente robustas, com 1-2,5 m de altura; inflorescências com muitos racemos (acima de 10).

21. Espiguetas orbiculares, obtusas.

22. Inflorescências com até 50 ramos; antécio superior totalmente coberto pela gluma superior, lema inferior com uma depressão no centro

20. P. millegrana

22'. Inflorescências com mais de 60 ramos; antécio superior não totalmente coberto, ou seja, parcialmente visível, lema inferior plano

8. P. densum

21 '. Espiguetas elípticas, agudas ou apiculadas.

23. Inflorescências com (25)100-130 racemos. Espiguetas glabras, apiculadas

23'. Inflorescências com 6-39 racemos. Espiguetas pilosas

30. P. plenum

24. Inflorescências com 6-16 racemos. Espiguetas 3-3,3 mm compr., gluma superior com tricomas adpressos esbranquiçados. Base da planta com bainhas desfiadas 15. P. loefgrenii

24'. Inflorescências com 28-39 racemos. Espiguetas 2-2,5 mm compr., gluma superior com tricomas não

adpressos, de base ferrugínea. Base da planta com bainhas inteiras

7. P. coryphaeum

20 '. Plantas pequenas, com até $1 \mathrm{~m}$ de altura; inflorescência com poucos racemos (menos de 10 racemos).

25. Inflorescências terminais com apenas 1 racemo (em $P$. arenarium pode ocorrer com 2 ramos), inflorescências axilares presentes.

26. Lâminas foliares lineares, densamente pilosas a hirsutas; lígula 0,1-1 mm compr.; espiguetas dispostas alternativamente em posição adaxial e abaxial (disposição "thrasyoide" sensu Burman 1985) ....... 34. P. robustum 26'. Lâminas foliares lanceoladas a linear-lanceoladas, glabras ou pilosas; lígula 1-2,5 mm compr.; espiguetas não dispostas alternativamente em posição adaxial e abaxial.

27. Espiguetas com tricomas tuberculados com base dourada.

2.P. arenarium

27'. Espiguetas glabras ..... 28. Lâminas foliares 4,5-12,5 cm compr., lanceoladas; inflorescências 3,5-5,5 cm compr.; espiguetas 1,9-2 mm compr.

24. P. nutans

28'. Lâminas foliares 13-28 cm compr., linear-lanceoladas; inflorescências 10-13 cm compr.; espiguetas

2,8-3 mm compr.

28. P. pilosum 
25'. Inflorescências terminais sempre com 2 racemos ou mais, inflorescências axilares ausentes.

29. Espiguetas escudadas 38. P. scutatum

29'. Espiguetas ovais, oval-elípticas, elípticas, obovais, orbiculares ou oblongas.

30. Lâminas foliares com base atenuada; espiguetas com tricomas adpressos.

31. Espiguetas 1,8-2 mm compr.

32. Espiguetas elípticas, agudas, 0,8-1 mm larg.

32 '. Espiguetas obovais, obtusas, 1,3-1,5 mm larg 25. P. oligostachyum

$31^{\prime}$. Espiguetas 2,5-2,8 mm compr. 6. $P$. corcovadense

30'Lâminas foliares com base arredondada ou truncada; espiguetas glabras ou pilosas, tricomas adpressos ausentes.

33. Plantas anuais; espiguetas pilosas com tricomas clavados4. P. clavuliferum

33'. Plantas perenes; espiguetas glabras ou pilosas com tricomas tuberculados ou velutinos.

34. Plantas muito ramificadas, colmos com 10-20 nós.

37. P. scalare

34'. Plantas pouco ramificadas, colmos com 2-6 nós.

35. Espiguetas glabras.

36. Plantas decumbentes; lâminas foliares lanceoladas 1-1,5 cm larg.

18. P. mandiocanum

36'. Plantas eretas; lâminas foliares lineares 0,2-0,5 cm larg.

37. Espiguetas apiculadas, maior do que o antécio superior

29. P. aff. planum

37'. Espiguetas arredondadas até agudas, não apiculadas, do mesmo comprimento do antécio superior.

38. Plantas com bainhas desfiadas na base; lâminas foliares pilosas 39. P. trichostomum

38'. Plantas com bainhas inteiras na base; lâminas foliares glabras.

39. Bainhas foliares velutinas; inflorescência com ramos 1,5-4,5 cm compr., os inferiores não ultrapassando a ápice do eixo principal; espiguetas estreitamente elípticas, 1-1,2 $\mathrm{mm}$ larg. 36. $P$. rupium 39'. Bainhas foliares glabras; inflorescências com ramos 8-12 cm compr., os inferiores ultrapassando a ápice do eixo principal; espiguetas elípticas a obovadas, ca. 1,5 $\mathrm{mm}$ larg.

13. P. ligulare

35'. Espiguetas pilosas.

40. Inflorescências com 10-14(50) ramos; espiguetas orbiculares, 1,3-1,5 mm compr. .... 26. P. paniculatum 40’. Inflorescências com (1)2-4(10) ramos; espiguetas elípticas, 2,2-4 mm compr.

41. Inflorescência com ráquis 1-1,2 mm larg.; espiguetas 2,2-2,5 mm compr., gluma superior com longos cílios radiados nas margens, entremeadas por tricomas mais curtos31. P. polyphyllum 41'. Inflorescências com ráquis 0,8-1 mm larg.; espiguetas 3,5-4 mm compr., densamente vilosas

9. P. erianthum

Paspalum ammodes Trin., Gram. Panic. 120. 1826. (Fig. 3 A; Figs. 6 A-E)

Plantas perenes, cespitosas, $30-70 \mathrm{~cm}$ alt. Colmos com 4-5 nós, não invaginados. Folhas concentradas na base da planta; bainhas não desfiadas, não infladas, glabras, as inferiores geralmente densamente pilosas, margens glabras a pilosas; lígula 0,3-0,5 mm compr.; aurículas ausentes; lâminas 11,5-14 x 0,02 cm, lineares, planas, pilosas, base arredondada. Inflorescências terminais 5,6-7,5 cm compr., com 3-6 racemoss alternos, as axilares ausentes; ráquis sem alas laterais. Espiguetas 3-3,5 x 1,2-1,5 mm, solitárias, pediceladas, elípticas, agudas, não apiculadas, esverdeadas, sem máculas; gluma inferior ausente; gluma superior 3-3,5 mm compr., 5-nervada, pilosa, com tricomas tuberculados na base, não papilosa, não ciliada nas margens; lema inferior 3-3,5 mm compr., 5-nervado, piloso, com tricomas com base tuberculada, não hialino, não papiloso, plano, margens glabras; antécio inferior estéril, pálea ausente; antécio superior 3-3,2 x 1,1-1,3 mm, não estipitado, elíptico, ápice agudo, glabro, levemente papiloso, estramíneo. Cariopse não vista.
Material examinado: BRASIL, BAHIA: Rio de Contas, 23.I.1974, fl., R.M. Harley 15466 (CEN, CEPEC, IPA). Material adicional: BRASIL, BAHIA, Formosa do Rio Preto, 15.XI.1995, fl., R.C. Oliveira 362 (CEN).

Ocorre desde a Venezuela e Guiana até o Brasil, Bolívia e Paraguai (Zuloaga \& Morrone 2005), e no Brasil ocorre em todas as regiões (Flora do Brasil 2020). Paspalum ammodes caracteriza-se pelas lâminas foliares lineares e espiguetas solitárias e pilosas. Os materiais analisados no presente trabalho possuem até seis ramos, contrastando com os materias analisados em Oliveira \& Valls (2002) que têm até quatro ramos. Habita geralmente campos abertos, sujeitos a queimadas naturais periódicas (Morrone et al. 2004). Na Chapada Diamantina é encontrada principalmente em áreas de campo rupestre e cerrado.

Paspalum arenarium Schrad. ex Schult., Mant. 2. 172. 1824.

(Fig. 3 B; Figs. 6 F, G)

Plantas perenes, cespitosas, $36-76 \mathrm{~cm}$ alt. Colmos com ca. 3 nós, não invaginados. Folhas concentradas na 

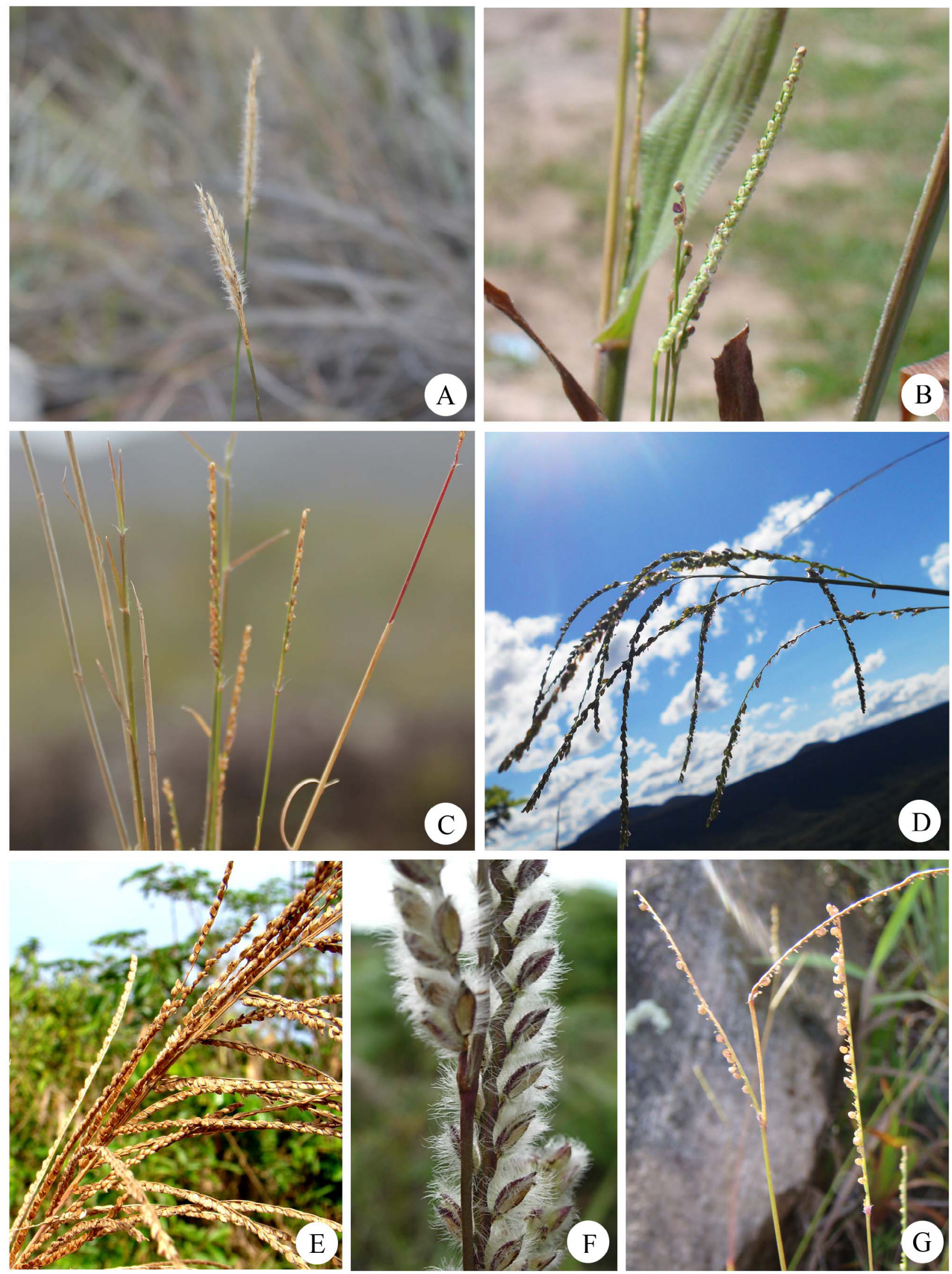

Figs. 3A-G. Inflorescências: A. Paspalum ammodes; B. P. arenarium; C. P. clavuliferum; D. P. corcovadense; E. P. coryphaeum; F. P. erianthum; G. P. giuliettiae. Fotos: Fig. F (G.H. Rua); Figs. B, D, E, G ( K.M. Pimenta); Figs. A, C (R.P. Oliveira). 
base; bainhas não desfiadas, não infladas, pilosas, margens glabras, sésseis; lígula 1-1,5 mm compr.; aurículas ausentes; lâminas 6,5-13 x 0,2 cm, lanceoladas, planas, glabras, margens ciliadas, base arredondada. Inflorescências terminais 5-12 cm compr., com 1-2 racemos, quando 2, então alternos; inflorescências axilares presentes; ráquis sem alas laterais. Espiguetas 1,2-1,4 x $1 \mathrm{~mm}$, pareadas, pediceladas, obovais, obtusas, não apiculadas, esverdeadas a paleáceas, sem máculas; gluma inferior ausente; gluma superior 1,2-1,4 mm compr., 3-nervada, pilosa, com tricomas tuberculados com base dourada, não papilosa, não ciliada nas margens; lema inferior 1,2-1,4 mm compr., 2-nervado, piloso, com tricomas tuberculados com base dourada, não hialino, não papiloso, margens glabras; antécio inferior estéril, pálea ausente; antécio superior 1,2-1,4 x 1 $\mathrm{mm}$, não estipitado, elíptico, ápice obtuso, piloso apenas no ápice, liso, estramíneo. Cariopse não vista.

Material examinado: BRASIL, BAHIA: Lençóis, 20.IV.1997, fl., R.M. Harley et al. 28631 (HUEFS). Morro do Chapéu, 30.IV.2011, fl., E. Melo et al. 9670 (HUEFS).

Ocorre na Guiana, Guiana Francesa e Brasil (Renvoize 1984; Oliveira \& Valls 2001), onde é encontrado em todas as regiões, exceto no Centro-Oeste (Flora do Brasil 2020). Paspalum arenarium é reconhecida pelas espiguetas pilosas, com tricomas tuberculados de base dourada, e pela presença de inflorescências axilares. O caráter sem máculas de suas espiguetas pode gerar confusão, devido à coloração dourada na base dos tricomas, tornando a espigueta aparentemente com máculas. Porém, esta possui coloração uniforme, e a cor dourada pertence aos tricomas. Seu hábito pode ser confundido com P. clavuliferum C. Wright pelas folhas concentradas na base, porém, em $P$. clavuliferum as folhas são lineares e densamente concentradas. Na Chapada Diamantina é encontrada principalmente em áreas de caatinga e cerrado.

Paspalum carinatum Humb. \& Bonpl. ex Fluggé, Gram. Monogr. 65. 1810.

(Figs. $6 \mathrm{H}-\mathrm{L}$ )

Plantas perenes, cespitosas, $36-76 \mathrm{~cm}$ alt. Colmos com 3-4 nós, não invaginados. Folhas concentradas na base; bainhas não desfiadas, não infladas, pilosas, as inferiores vilosas, margens glabras; lígula ca. $0,5 \mathrm{~mm}$ compr.; aurículas ausentes; lâminas $6,5-13 \times 0,2 \mathrm{~cm}$, lineares a filiformes, convolutas, subglabras a densamente pilosas, base truncada. Inflorescências terminais 5-12 cm compr., 1-(2) racemos alternos; inflorescências axilares ausentes; ráquis com alas laterais estreitas, membranáceas, $3,5-4 \mathrm{~mm}$ larg. Espiguetas 4-5 x 1,5-2 mm, solitárias, pediceladas, oval-elípticas, obtusas, não apiculadas, paleáceas a estramíneas, sem máculas; gluma inferior ausente; gluma superior 3-nervada, pilosa no terço basal, tricomas longos em $1 / 3$ da espigueta, não papilosa, margens ciliadas no ápice; lema inferior 3,5-4,5 mm, 5-nervado, piloso no terço basal, com tricomas longos, não hialino, não papiloso, margens curtamente ciliadas no ápice; antécio inferior estéril, pálea ausente; antécio superior 2,8-3,5 x 1-1,2 $\mathrm{mm}$, não estipitado, elíptico, ápice obtuso, pubescente no ápice, liso, estramíneo. Cariopse ca. 1,4 x 0,8 mm, obdeltoide, castanha.

Material examinado: BRASIL, BAHIA: Abaíra, 1.II.1992, fl., E.N. Lughadha \& R.F. Queiroz 51029 (SPF). Lençóis, 20.IV.1997, fl., R.M. Harley et al. 28631 (HUEFS). Mucugê, 13.II.1997, fl., L. Passos et al. 5554 (ALCB, HUEFS). Umburanas, 11.IV.1999, L.P. Queiroz et al. 5354 (HUEFS).

Ocorre na Guiana, Peru e Brasil (Oliveira \& Valls 2001). No Brasil, ocorre em todas as regiões (Flora do Brasil 2020). Paspalum carinatum caracteriza-se pela inflorescência com ráquis apresentando alas laterais membranáceas estreitas, 3,5-4 $\mathrm{mm}$ de comprimento, e espiguetas com longos tricomas no terço basal. Pode ser confundida com $P$. stellatum Fluggé, porém esta possui ráquis com alas bem mais largas $(5-10 \mathrm{~mm})$, e quando na inflorescência há dois ramos, estes são conjugados; enquanto que em $P$. carinatum a ráquis possui alas com 3,5-4 $\mathrm{mm}$ de largura, e quando há dois ramos na inflorescência, estes são alternos (Denham et al. 2002; Sendulsky \& Burman 1978; Zuloaga $\&$ Morrone 2005). Na Chapada Diamantina é encontrada principalmente em áreas de campo rupestre e cerrado.

Paspalum clavuliferum C. Wright, Fl. Club. 195. 1871. (Fig. 3 C; Figs. 6 M-Q)

Plantas anuais, cespitosas, $13-32 \mathrm{~cm}$ alt. Colmos com 3-4 nós, não invaginados. Folhas concentradas na base; bainhas não desfiadas, não infladas, pilosas, as inferiores glabras a pilosas, margens pilosas; lígula $1-1,5 \mathrm{~mm}$ compr.; aurículas ausentes; lâminas 2,5-14 x 0,1-0,3 cm, lineares, planas, pilosas, base truncada. Inflorescências terminais 2-5 cm compr., 2(3) racemos alternos; axilares ausentes; ráquis sem alas laterais. Espiguetas 1-1,2 x 0,5 mm, pareadas, espiguetas secundárias freqüentemente rudimentares, pediceladas, obovais, agudas, não apiculadas, esverdeadas, raramente com manchas vináceas; gluma inferior ausente; gluma superior 0,9-1 mm compr., 3-nervada, pilosa, com tricomas clavados, não papilosa, não ciliada nas margens; lema inferior 1-1,2 mm compr., 3-nervado, glabro, não hialino, não papiloso, margens glabras; antécio inferior estéril, pálea ausente; antécio superior $1-1,2 \times 0,5 \mathrm{~mm}$, não estipitado, oboval, ápice agudo, glabro, papiloso, estramíneo. Cariopse ca. 0,8 x 0,6 mm compr., oval, verde. Material examinado: BRASIL, BAHIA: Morro do Chapéu, 3.V.2007, fl., R.P. Oliveira \& G.H. Rua 1257 (HUEFS); 19.II.2012, fl., K.M. Pimenta \& R.P. Oliveira 305 (HUEFS).

Ocorre do México ao Brasil (Renvoize 1984). Neste último, foi registrada em todas as regiões, exceto na Sul (Flora do Brasil 2020). Paspalum clavuliferum caracterizase pela presença de tricomas clavados na gluma superior. O material analisado não possui folhas densamente pilosas em ambas as faces, como ocorre no material citado por 
Maciel et al. (2009) para Pernambuco. Ao contrário, estas são pilosas apenas nas margens e na face adaxial. Pode ser confundida com $P$. arenarium, porém é diferenciada pelas folhas lineares concentradas na base e pelos tricomas clavados, enquanto que em $P$. arenarium as folhas são lanceoladas e os tricomas tuberculados e dourados na base. $\mathrm{Na}$ Chapada Diamantina é encontrada principalmente em áreas de caatinga.

Paspalum conjugatum P.J. Bergius, Acta Helv. Phys.Math. 7:129. 1772.

(Figs. 7 A-C)

Plantas perenes, estoloníferas, $25-30 \mathrm{~cm}$ alt. Colmos com 2-3 nós, não invaginados. Folhas distribuídas ao longo do colmo; bainhas não desfiadas, não infladas, glabras, margens pilosas; lígula $0,5 \mathrm{~mm}$ compr.; aurículas ausentes; lâminas 2,8-7,2 x 0,5-1 cm, lanceoladas, planas, escabras, base arredondada. Inflorescências terminais 5-9 $\mathrm{cm}$ compr., 2 racemos conjugados, as axilares presentes ou ausentes; ráquis sem alas laterais. Espiguetas 1,5-1,7 x 1-1,2 mm, solitárias, pediceladas, ovais, agudas, apiculadas, paleáceas, sem máculas; gluma inferior ausente; gluma superior 1,51,7 mm compr., 2-nervada, longamente ciliada nas margens, com tricomas longos, não papilosas; lema inferior 1,4-1,6 mm compr., 2-nervado, glabro, não hialino, não papiloso, margens glabras; antécio inferior estéril, pálea ausente; antécio superior ca. $1,3 \times 1,5 \mathrm{~mm}$, não estipitado, oval, ápice agudo, glabro, liso, estramíneo. Cariopse não vista. Material examinado: BRASIL. BAHIA: Andaraí, 13.X.2012, fl., K.M. Pimenta et al. 541 (HUEFS).

Ocorre principalmente nos trópicos, sendo menos comum no hemisfério oriental (Oliveira \& Valls 2001). No Brasil ocorre em todas as regiões (Flora do Brasil 2020). Paspalum conjugatum caracteriza-se pelo hábito estolonífero, inflorescência com dois racemos conjugados e espiguetas pequenas, amareladas e longamente ciliadas nas margens. Apesar de ser uma espécie comum em florestas, na Chapada Diamantina foi encontrada apenas no Morro do Castelo, em Andaraí, em uma área de mata de galeria na base do morro, como é uma área com poucas coletas nunca havia sido registrada para a região.

Paspalum corcovadense Raddi, Agrostogr. Bras. 27. 28. 1823.

(Fig. 3 D; Figs. 7 D-F)

Plantas perenes, cespitosas, $80-100 \mathrm{~cm}$ alt. Colmos com 4-7 nós, não invaginados. Folhas concentradas na base; bainhas não desfiadas, não infladas, glabras, as inferiores grabras, margens pilosas; lígula 1-1,3 mm compr.; aurículas ausentes; lâminas 14,5-29 x 0,9-1,3 cm, lanceoladas, planas, pilosa apenas na face abaxial, base atenuada. Inflorescências terminais 13-14 cm compr., (2)5-6 racemos alternos; inflorescências axilares ausentes; ráquis sem alas laterais. Espiguetas 2,5-2,8 x 1,5 mm, pareadas, pediceladas, elípticas, agudas, não apiculadas, esverdeadas; gluma inferior ausente, sem máculas; gluma superior 2-2,2 mm compr., 3-nervada, glabra a pilosa, tricomas adpressos, não papilosas, não ciliada nas margens; lema inferior 2,52,8 mm compr., 3-5(7) nervado, glabro, não hialinos, não papilosos, margens glabras; antécio inferior estéril, pálea ausente; antécio superior 2-2,2 x 1-1,2 mm, não estipitado, elíptico, ápice obtuso, glabro, liso, estramíneo. Cariopse ca. 1 x $0,8 \mathrm{~mm}$, suborbicular, estramínea.

Material examinado: BRASIL, BAHIA: Andaraí, 13.X.2012, fl., K.M. Pimenta et al. 539 (HUEFS). Maracás, 22.IV.2002, fl., K.R.B. Leite et al. 219 (HUEFS). Mucugê, 31.IX.2011, fl., K.M. Pimenta \& R.P. Oliveira 277 (HUEFS).

Ocorre em regiões tropicais e subtropicais da América do Sul (Oliveira \& Valls 2001). No Brasil, distribui-se no Nordeste, Sudeste e Sul (Flora do Brasil 2020). Paspalum corcovadense caracteriza-se pela base atenuada da lâmina e pela gluma superior mais curta que a espigueta, deixando o ápice do antécio superior visível. É semelhante a $P$. oligostachyum Salzm. ex Steud., porém as espiguetas obovais com até $2 \mathrm{~mm}$ de comprimento, antécios levemente papilosos e cariopse orbicular e castanha de $P$. oligostachyum se contrapõem às espiguetas elípticas com mais de $2,5 \mathrm{~cm}$ de comprimento, antécios lisos e cariopse suborbicular e estramínea de $P$. corcovadense.

Paspalum molle também possui um estreitamento na base da lâmina foliar; porém as lâminas foliares nessa espécie são mais compridas do que a bainha, e as espiguetas menores que $2 \mathrm{~mm}$ de comprimento, enquanto que em $P$. corcovadense lâminas e bainhas apresentam menores diferenças no comprimento, que em alguns casos são equitativas, e as espiguetas excedem $2,5 \mathrm{~mm}$ de comprimento.

Foi verificado ao longo do estudo que $P$. corcovadense possui ampla variação morfológica, principalmente no comprimento $(14,5-29 \mathrm{~cm})$ e na disposição das lâminas foliares, as quais estão concentradas na base ou distribuídas ao longo do colmo, e no tamanho e número de ramos da inflorescência. $\mathrm{Na}$ Chapada Diamantina é encontrada em áreas de floresta.

Paspalum coryphaeum Trin., Gram. Panic. 144. 1826. (Fig. 3 E; Figs. 7 G, H)

Plantas perenes, cespitosas, $41-100 \mathrm{~cm}$ alt. Colmos com ca. 4 nós, não invaginados. Folhas concentradas na base; bainhas levemente desfiadas, não infladas, glabras a pilosas, as inferiores glabras, margens glabras a pilosas; lígula ca. 1-2 mm compr.; aurículas ausentes; lâminas $15,5-52 \times 0,5-1,5 \mathrm{~cm}$, linear-lanceoladas, planas, glabras, base não atenuada. Inflorescências terminais $22-34 \mathrm{~cm}$ compr., racemosas, 28-39 racemos; inflorescências axilares ausentes; ráquis sem alas laterais. Espiguetas 2-2,5 x 0,8-1 mm, pareadas, pediceladas, elípticas, agudas, não 
apiculadas, castanhas, sem máculas; gluma inferior ausente; gluma superior 3-nervada, pubescente com tricomas curtos de base ferrugínea, não ciliada nas margens; lema inferior 2-2,2 mm compr., 3-nervado, glabro, não hialino, não papiloso, margens glabras; antécio inferior estéril, pálea ausente; antécio superior 2-2,5 x 0,8-1 mm, não estipitado, elíptico, ápice obtuso, totalmente glabro, liso, estramíneo. Cariopse não vista.

Material examinado: BRASIL, BAHIA: Morro do Chapéu, 5.V.2007, fl., R.P. Oliveira et al. 1304 (HUEFS). Mucugê, 13.II.1997, fl., E. Saar et al. 5580 (ALCB, HUEFS). Rio de Contas, 3.III.2004, fl., R.M. Harley \& A.M. Giulietti 55012 (HUEFS).

Ocorre no Panamá, Trindade, Guiana e Brasil (Oliveira \& Valls 2001). No Brasil, distribui-se na maioria das regiões, execeto na região Sul (Flora do Brasil 2020). Paspalum coryphaeum caracteriza-se principalmente pela inflorescência com vários ramos e espiguetas castanhas pubescentes. Em Barreto (1966) a espécie é tratada como decumbente, porém foram aqui verificadas apenas plantas cespitosas, assim como constatado por Oliveira \&Valls (2001) e Maciel et al. (2009). De fato, as plantas modificam seu hábito com a idade e a situação em que crescem (Chase 1929). Na Chapada Diamantina foram observados materiais mais constantes, exceto por $S$. Atkins et al. 5580, que apresentou-se mais robusto do que os demais, com folhas maiores, $52 \mathrm{~mm}$ de comprimento, e lígula ca. $10 \mathrm{~mm}$ de comprimento. Na Chapada Diamantina é encontrada principalmente em áreas de caatinga e floresta.

Paspalum densum Poir., Encycl. Suppl. 5:32. 1804. (Figs. 7 I-L)

Plantas perenes, cespitosas, ca. $100 \mathrm{~cm}$ alt. Colmos com ca. 5 nós, não invaginados. Folhas concentradas na base; bainhas não desfiadas, não infladas, glabras, as inferiores glabras, reticuladas, margens glabras; lígula 3-3,2 mm compr.; aurículas ausentes; lâminas 15-36 x 1,6 $\mathrm{cm}$, lanceoladas, conduplicadas, glabras, base truncada. Inflorescências terminais ca. $23 \mathrm{~cm}$ compr., ca. 46 racemos alternos; inflorescências axilares ausentes; ráquis sem alas laterais. Espiguetas 2-2,5 x 1,5 mm, pareadas, pediceladas, orbiculares, obtusas, levemente apiculadas, castanhas, sem máculas; gluma inferior ausente; gluma superior 1,9-2,3 mm compr., 3-nervada, glabra, não papilosa, não ciliada nas margens; lema inferior 2-2,4 mm compr., 3-nervado, glabro, não hialino, não papiloso, margens glabras; antécio inferior estéril, pálea ausente; antécio superior 2-2,5 x 1,21,5 mm, não estipitado, orbicular, ápice obtuso, glabro, papiloso, estramíneo. Cariopse não vista.

Material examinado: BRASIL, BAHIA: Rio de Contas, 6.IV.1992, fl., G.M. Hatschbach \& E. Barbosa 56694 (HUEFS).

Ocorre nas Américas Central e do Sul (Oliveira \& Valls 2001), e no Brasil ocorre em todas as regiões (Flora do Brasil 2020). Paspalum densum é muito semelhante a $P$. millegrana Schrad., diferindo principalmente pelas inflorescências, as quais têm até 50 ramos, e segundo Renvoize (1984), não possuem formato piramidal, enquanto que em $P$. densum as inflorescências são piramidais e constituídas por mais de 60 ramos. Foi verificado ainda que em $P$. densum as espiguetas apresentam antécio visível e lema aplanado, enquanto que em $P$. millegrana o antécio apresenta-se totalmente coberto e o lema tem uma pequena depressão no centro. A identidade dessas duas espécies não está completamente esclarecida, e provavelmente existem muitas identificações duvidosas ou errôneas nos herbários. Na Chapada Diamantina é encontrada principalmente em áreas alteradas como borda de floresta, cerrado e caatinga.

Paspalum erianthum Nees ex Trin., Gram. Panic. 121. 1826.

$$
\text { (Fig. } 3 \text { F; Figs. } 7 \text { M, N) }
$$

Plantas perenes, cespitosas, (40)50-150 cm alt. Colmos com ca. 4 nós, não invaginados. Folhas distribuídas ao longo do colmo; bainhas desfiadas, não infladas, pilosas a vilosas, as inferiores vilosas, margens pilosas; lígula ca. 0,4 mm compr.; aurículas ausentes; lâminas 11-19 x $5 \mathrm{~cm}$, linear-lanceoladas, planas, pilosas, base truncada. Inflorescências terminais 6-16 cm compr., 3-4 racemos alternos a sobrepostos; inflorescências axilares ausentes; ráquis sem alas laterais. Espiguetas 3,5-4 x 2-1,5 mm, pareadas, pediceladas, elípticas, agudas, não apiculadas, esverdeadas com manchas vináceas; gluma inferior ausente; gluma superior 3,5-4 mm compr., 5-nervada, vilosa, com tricomas longos, não papilosa, não ciliada nas margens; lema inferior 3,4-3,9 mm compr., 3-nervado, piloso, não hialino, não papiloso, margens glabras; antécio inferior estéril, pálea ausente; antécio superior 3,5-3 x 1-1,5 mm, não estipitado, elíptico, ápice agudo, glabro, levemente papiloso, estramíneo. Cariopse ca. 2 × 0,8 mm, elíptica, castanha.

Material examinado: BRASIL, BAHIA: Abaíra, 10.I.1992, fl., R.F. Queiroz \& D.J.N. Hind 50057 (CEPEC, HUEFS, SPF); 30.XII.1993, fl., W. Ganev 2726 (HUEFS); 10.I.1994, fl., $W$. Ganev 2763 (HUEFS).

Ocorre do México ao norte do Uruguai (Morrone et al. 2004), e no Brasil ocorre em todas as regiões, sendo um novo registro para o estado da Bahia, com base na Flora do Brasil 2020. Paspalum erianthum caracteriza-se principalmente por apresentar nós pubescentes, bainhas velutinas, folhas pilosas e espiguetas pilosas a vilosas. $\mathrm{O}$ material D.J.N. Hind \& R.F. Queiroz 50057 apresentouse com um porte mais delicado, muito semelhante a $P$. sanguinolentum Trin. Muitos autores consideraram essas duas espécies como distintas (Trinius 1826; Chase 1929; Oliveira \& Valls 2001), porém atualmente a mesma é tratada como sinônimo de $P$. erianthum (Morrone et al. 2004). Segundo Sendulsky \& Burman (1978) P. sanguinolentum possui lâminas foliares de cor vemelho-púrpura e apresenta variação quanto ao grau de pilosidade das lâminas foliares e organização das espiguetas na ráquis, porém esse caráter não foi observado nos materiais da área de estudo. 
Paspalum erianthum possui provável influência do fogo em sua floração, uma vez que no material examinado fértil é evidente resquícios de folhas queimadas na base da planta. Este tipo de influência do fogo é um evento comum em muitas espécies de plantas que ocorrem na Chapada Diamantina (Harley et al. 2005). Na Chapada Diamantina é encontrada principalmente em áreas de cerrado.

Paspalum giuliettiae K.M. Pimenta, G.H. Rua \& R.P. Oliveira, Sys. Bot., 38.3. 2013.

(Fig. $3 \mathrm{G}$ )

Plantas perenes, cespitosas, $20-40 \mathrm{~cm}$ alt. Colmos com ca. 3 nós, não invaginados. Folhas concentradas na base; bainhas não desfiadas, não infladas, glabras, margens ciliadas; lígula ca. 0,5 mm compr.; aurículas ausentes; lâminas 2,5-11 x 0,9-1,2 cm, lanceoladas a lineares, planas, glabras, base arredondada. Inflorescências terminais 5-5,5 cm compr., 2(3) racemos alternos a subconjugados; inflorescências axilares presentes; ráquis sem alas laterais. Espiguetas 1,5-1,9 x 1-1,2 mm, solitárias, pediceladas, elípticas, obtusas a agudas, não apiculadas, esverdeadas, sem máculas; gluma inferior ausente; gluma superior 1,51,9 mm compr., 3-4-nervada, glabra, não papilosa, não ciliada nas margens; lema inferior 1,5-1,9 mm compr., 4-nervado, glabro, não hialino, não papiloso, margens glabras; antécio inferior estéril, pálea ausente; antécio superior 1,5-1,7 x 1-1,2 mm, não estipitado, elíptico a oboval, ápice obtuso a agudo, glabro, papiloso, estramíneo. Cariopse ca. $1 \mathrm{~mm}$, oboval, castanha.

Material examinado: BRASIL, BAHIA: Andaraí, 13.X.2012, fl., K.M. Pimenta et al. 528 (HUEFS). Ibicoara, 20.IX.2012, fl., K.M. Pimenta et al. 499 (HUEFS). Mucugê, 01.X.2011, fl., K.M. Pimenta \& C.Silva 281 (HUEFS).

Endêmica do Brasil, conhecida apenas do estado da Bahia, na região da Chapada Diamantina (Pimenta et. al. 2013). Paspalum giuliettiae é morfologicamente relacionada ao grupo informal Notata, semelhante a P. pumilum Nees, porém possui os ramos da inflorescência separados por um entrenó conspícuo com 0,6-1 cm de comprimento. e inflorescência axilar com 1-2 ramos, ausente em P. pumilum (Pimenta et al. 2013). Foi possível verificar a ocorrência de variação morfológica dentro dessa espécie quanto ao formato das lâminas foliares, que variam de lanceoladas a lineares, assim como no ápice dos antécios que variam entre agudos e obtusos. Na Chapada Diamantina é encontrada no campo rupestre, em áreas com solo encharcado.

Paspalum hyalinum Nees ex Trin., Gram. Panic. 103. 1826.

Plantas perenes, cespitosas, ca. $30 \mathrm{~cm}$ alt. Colmos com ca. 5 nós, não invaginados. Folhas concentradas na base; bainhas não desfiadas, não infladas, pilosas, as inferiores hirsutas, margens pilosas; lígula ca. $1 \mathrm{~mm}$ compr.; aurículas ausentes; lâminas 3,5-9 x 1-2 cm, lineares, planas, densamente pilosas, base arredondada. Inflorescências terminais ca. $4 \mathrm{~cm}$ compr., 2 racemos alternos; inflorescências axilares ausentes: ráquis sem alas laterais. Espiguetas ca. 1,8 x $1 \mathrm{~mm}$, solitárias, pediceladas, elípticas, agudas, não apiculadas, esverdeadas com manchas vináceas; gluma inferior ausente; gluma superior 1,81,9 mm, 2-nervada, glabra, não papilosa, não ciliada nas margens; lema inferior ca. 1,7 mm compr., (2)5-nervado, glabro, hialino no centro, não papiloso, margens glabras; antécio inferior estéril, pálea ausente; antécio superior 1,51,6 x 0,8-0,9 mm, não estipitado, elíptico, ápice obtuso, glabro, levemente papiloso, estramíneo. Cariopse não vista. Material examinado: BRASIL, BAHIA: Entre Rios, 17.III.2010, fl., J.G. Carvalho-Sobrinho \& R.F. Machado 2830 (HUEFS). Rio de Contas, 18.X.12, fl., R.P. Oliveira et al. 2176 (HUEFS).

Ocorre da Guiana até o Paraguai e Brasil (Oliveira \& Valls 2001). No Brasil ocorre em todas as regiões (Flora do Brasil 2020). Paspalum hyalinum caracteriza-se pela espigueta com até $1,8 \mathrm{~mm}$ de comprimento. e glabra com uma porção hialina no centro do lema superior. Assemelhase a $P$. minarum Hack., porém não apresenta a mancha em forma de $\mathrm{V}$ no lema superior característica dessa espécie. Segundo Sendulsky \& Burman (1980) pode ser encontrada em diversos ambientes, sugerindo uma ampla tolerância ambiental.

Paspalum lanciflorum Trin., Sp. Gram. 3. 286. 1829. (Fig. 4 A; Figs. 7 O-S)

Plantas perenes, cespitosas, $70-150 \mathrm{~cm}$ alt. Colmos com ca. 4 nós, não invaginados. Folhas distribuídas ao longo do colmo; bainhas não desfiadas, não infladas, pilosas, as inferiores glabras a pilosas, margens glabras; lígula 3,5-4 mm compr.; aurículas ausentes; lâminas 12,5-18 x 0,5-0,7 cm, linear-lanceoladas, planas, hirsutas, base truncada. Inflorescências terminais 8-11 cm compr., (2)3-5 racemos subconjugados; inflorescências axilares ausentes; ráquis com alas laterais membranáceas amareladas até castanhas, 5-6 mm larg. Espiguetas 4,5-7 x 1,9-2,1 mm, solitárias, sésseis, lanceoladas, agudas, não apiculadas, paleáceas, sem máculas; gluma inferior ausente; gluma superior 3-nervada, pilosa, com tricomas longos na base, não papilosa, ciliada nas margens; lema inferior 5,5-6 $\mathrm{mm}$ compr., glabro, não hialino, não papiloso, ciliado nas margens; antécio inferior estéril, pálea ausente; antécio superior 3-4 x $1 \mathrm{~mm}$, estipitado, linear, ápice agudo, glabro, escabro no ápice, liso, estramíneo. Cariopse não vista.

Material examinado: BRASIL, BAHIA: Abaíra, 13.IV.1992, fl., W. Ganev 144 (HUEFS); 30.V.2003, fl., M.J.G Andrade \& A.S. Conceição 333 (HUEFS). Barra da Estiva, 22.V.1991, fl., E.B. Santos \& S. Mayo 261 (CEPEC). Rio de Contas, 16.IV.2003, fl., A.M. Giulietti et al. 2240 (HUEFS).

Ocorre no Panamá, Colômbia, Guiana, Suriname, Venezuela, Brasil e Bolívia. No Brasil, ocorre nas Regiões Norte, Nordeste, Centro-Oeste e Sudeste (Flora do Brasil 2020), sendo um novo registro de ocorrência para a Bahia. Paspalum lanciflorum é reconhecido pelas inflorescências 

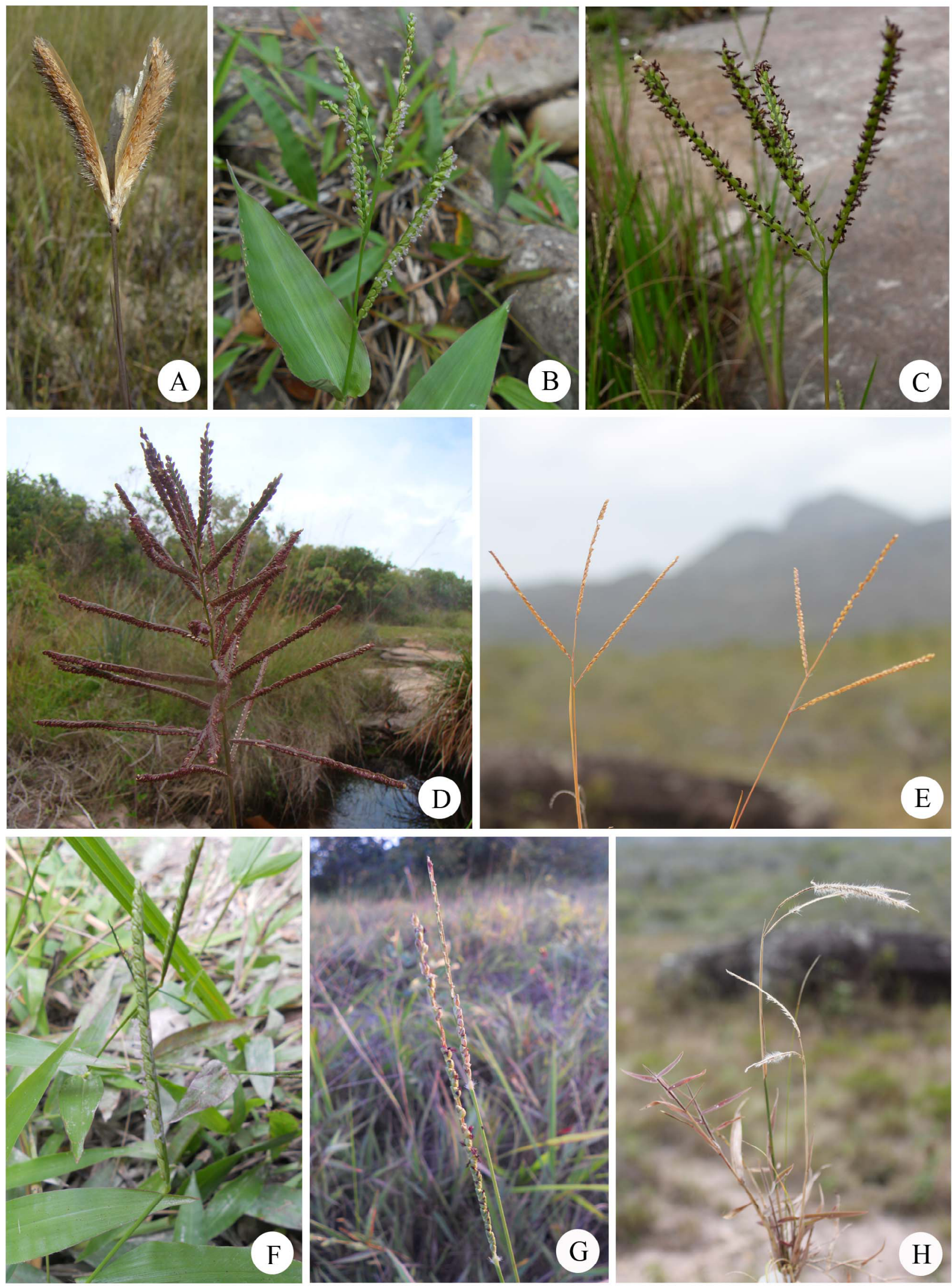

Figs. 4A-G. Infloresncências: H. Hábito; A. Paspalum lanciflorum; B. P. mandiocanum; C. P. madorence; D. P. millegrana; E. P. minarum; F. P. nutans; G. P. pilosum; H. P. polyphyllum. Hábito. Fotos: Fig. A (A.A. Conceição); Fig. C (G.H. Rua); Figs. B, D, E, F G (K.M. Pimenta); Fig. H (R.P. Oliveira). 
com 3-5 ramos subconjugados, com alas laterais de 5-6 $\mathrm{mm}$ de largura, douradas, e espiguetas lanceoladas e pilosas. Esta espécie é muito semelhante a P. stellatum, sendo diferenciadas principalmente pelo número de ramos da inflorescência, a qual em $P$. lanciflorum apresentase com 3-6 ramos (vs. 1(2) ramos em P. stellatum) e o tamanho das espiguetas, 4,5-7 $\mathrm{mm}$ de comprimento em $P$. lanciflorum vs. 2,4-4 mm de comprimento em P. stellatum (Denham et al. 2002). Na Chapada Diamantina é encontrado principalmente em áreas de cerrado e campo rupestre.

Paspalum ligulare Nees, Fl. Bras. Enum. 2:60. 1829. (Figs. 7 T-W)

Plantas perenes, cespitosas, ca. $60 \mathrm{~cm}$ alt. Colmos com ca. 4 nós, não invaginados. Folhas distribuídas ao longo do colmo; bainhas não desfiadas, não infladas, glabras, as inferiores não velutinas na base, margens glabras; lígula 1,6-4 mm compr.; aurículas ausentes; lâminas 7-41 x 0,3$0,5 \mathrm{~cm}$, lineares, planas, glabra a pilosa, base truncada. Inflorescências terminais $16-17 \mathrm{~cm}$ compr., 8-9 racemos alternos; inflorescências axilares ausentes; ráquis sem alas laterais. Espiguetas ca. 2,5 x 1,5 mm, pareadas, pediceladas, oblongas, agudas, apiculadas, esverdeadas, sem máculas; gluma inferior ausente; gluma superior ca. 2,5 x 1,5 mm compr., 3-nervada, glabra, sem tricomas, não papilosas, não ciliada nas margens; lema inferior 2,5-1,4 mm compr., 3-nervado, glabro, não hialino, não papiloso, margens glabras; antécio inferior estéril, pálea ausente; antécio superior 2,4-2,5 x 2,5 mm, não estipitado, oblongo, ápice agudo, glabro, papiloso, estramíneo. Cariopse não vista.

Material examinado: BRASIL, BAHIA: Morro do Chapéu, 3.V.2007, fl., R.P. Oliveira \& G.H. Rua 1268 (HUEFS).

Ocorre na América Central e Brasil (Swallen 1955). No Brasil ocorre nas regiões Nordeste e Sudeste (Flora do Brasil 2020). Até então, Paspalum ligulare não havia sido enquadrada em nenhum grupo informal, logo, por ser morfologicamente semelhante a Paspalum pleostachyum Döll, foi aqui inserida no grupo informal Caespitosa. Paspalum ligulare caracteriza-se pela sua lígula bem desenvolvida, com até $4 \mathrm{~mm}$ de comprimento, lâminas foliares lineares planas e espiguetas com até $2,5 \mathrm{~mm}$ de comprimento, com gluma superior e lema inferior glabros. $\mathrm{Na}$ Chapada Diamantina é encontrado principalmente em área de caatinga.

Paspalum lineare Trin., Gram. Panic. 99, 1826. (Figs. 8 A-D)

Plantas perenes, cespitosas, $46-52 \mathrm{~cm}$ alt. Colmos com ca. 3 nós, não invaginados. Folhas distribuídas ao longo do colmo; bainhas não desfiadas, não infladas, glabras a levemente pilosas, as inferiores geralmente velutinas na base, margens glabras a pilosas; lígula $3-5 \mathrm{~mm}$ compr.; aurículas ausentes; lâminas $10-20$ x 0,1 cm, filiformes, convolutas, glabras a pilosas, base truncada. Inflorescências terminais 4,5-9 cm compr., 2-3(4) racemos conjugados a subconjugados; inflorescências axilares ausentes; ráquis sem alas laterais. Espiguetas 4-5 x 1,3-2 mm, solitárias, pediceladas, elípticas, agudas, não apiculadas, esverdeadas, sem máculas; gluma inferior ausente; gluma superior 2,5-5 mm compr., (3)5-nervada, glabra a pilosa, com tricomas tuberculados na base, não papilosas, não ciliada nas margens; lema inferior 4-4,5 mm compr., 5-nervado, glabro, não hialino, não papiloso, margens glabras; antécio inferior estéril, pálea ausente; antécio superior 4-4,5 x 1-1,5 mm, elíptico, ápice obtuso, glabro, liso, estramíneo. Cariopse não vista.

Material examinado: BRASIL, BAHIA: Cascavel, 21.III.1999, fl., R.M. Harley et al. 53564 (HUEFS). Piatã, 26.XII.1992, fl., R.M. Harley et al. 50411 (CEPEC, HUEFS, SPF). Rio de Contas, 10.VIII.2000, fl., R.P. Oliveira et al. 612 (HUEFS).

Ocorre na Costa Rica, Cuba e Antilhas, até Argentina e Brasil (Oliveira \& Valls 2001). No Brasil ocorre em todas as regiões (Flora do Brasil 2020). Paspalum lineare possui nós barbados (Trinius 1826; Chase 1929), apesar da variação desse caráter citada por Oliveira \& Valls (2002), nos materiais da Chapada Diamantina os caracteres mantiveram-se constantes. O material analisado tem evidências de fogo antes da floração, evidenciando relação fenológica com a queima periódica da vegetação (Zuloaga \& Morrone 2005). Embora normalmente a gluma superior esteja ausente nessa espécie, no material $A . A$. Conceição 4157 foi verificada a presença dessa estrutura, porém reduzida. Na Chapada Diamantina é encontrado em áreas de cerrado e campo rupestre.

Paspalum loefgrenii Ekman, Ark. Bot. 10(17):15 1911. (Fig. 8 E)

Plantas perenes, cespitosas, $90-150 \mathrm{~cm}$ alt. Colmos com ca. 3 nós, não invaginados. Folhas distribuídas ao longo do colmo; bainhas desfiadas na base, não infladas, glabras, as inferiores vilosas na base, margens glabras; lígula ca. 1,5 mm compr.; aurículas ausentes; lâminas $25,5-53$ x 0,7-1,5 $\mathrm{cm}$, linear-lanceoladas, planas, glabra a levemente pilosas, base truncada. Inflorescências terminais $18-30 \mathrm{~cm}$ compr., 10-14 racemos alternos; inflorescências axilares ausentes; ráquis sem alas laterais. Espiguetas 3-3,2 x 1,5 mm, pareadas, pediceladas, elípticas, agudas, não apiculadas, esverdeadas com manchas vináceas; gluma inferior ausente; gluma superior 2,9-3 mm compr., 5-nervada, pilosa, com tricomas adpressos, não papilosas, não ciliada nas margens; lema inferior 3-3,2 mm compr., 3-nervado, piloso, não hialino, não papiloso, margens glabras; antécio inferior estéril, pálea ausente; antécio superior 2,9-3 x 1,5 mm, não estipitado, elíptico, ápice agudo, glabro, levemente papiloso, estramíneo. Cariopse não vista.

Material examinado: BRASIL, BAHIA: Mucugê, 13.II.1997, fl., L. Passos et al. 5552 (ALCB, HUEFS). Rio de Contas, 2.II.1997, fl., B. Stannard et al. 4870 (ALCB, HUEFS). Umburanas, 1.IV.1999, fl., L.P. Queiroz et al 5313 (HUEFS). 
Ocorre na Guiana e Brasil (Renvoize 1984). No Brasil ocorre nas regiões Norte e Nordeste (Flora do Brasil 2020). Paspalum loefgrenii é distinta das demais espécies da área de estudo pelo conjunto de folhas alongadas, com 25,5$53 \mathrm{~cm}$ de comprimento, e base da planta com bainhas senescentes desfiadas, formando um emaranhado de folhas secas, e espiguetas com ápice agudo. O antécio de $P$. loefgrenii possui um estreitamento na base, não sendo, porém, estipitado. O material A.A. Conceição 3148 apresentou-se com um porte mais delicado que os demais materiais analizados, com base foliar densamente vilosa e pouco desfiada. Na Chapada Diamantina é encontrado em áreas de cerrado e campo rupestre.

\section{Paspalum maculosum Trin., Gram. Panic. 98. 1826.} (Figs. 8 F-J)

Plantas perenes, rizomatosas, ca. $100 \mathrm{~cm}$ alt. Colmos com ca. 9 nós, não invaginados. Folhas distribuídas ao longo do colmo; bainhas não desfiadas, não infladas, pilosas a vilosas, as inferiores glabras, margens glabras a pilosas; lígula ca. $0,5 \mathrm{~mm}$ compr.; aurículas ausentes; lâminas ca. $30 \times 0,2 \mathrm{~cm}$, filiformes, convolutas, pilosas, base truncada. Inflorescências terminais ca. 7,5 cm compr., 2 racemos conjugados; inflorescências axilares ausentes; ráquis sem alas laterais. Espiguetas 2,2-2,5 x 1,2 mm, solitárias, pediceladas, elípticas, agudas, não apiculadas, castanhas com máculas douradas; gluma inferior ausente; gluma superior 2,2-2,5 mm compr., 5-nervada, glabra, papilosa, não ciliada nas margens; lema inferior 2,5-2,2 mm compr., 3-nervado, glabro, não hialino, não papiloso, margens glabras; antécio inferior estéril; pálea ausente; antécio superior 2,2-2,5 x 1,2 mm, não estipitado, elíptico, ápice obtuso, glabro, liso, estramíneo. Cariopse não vista. Material examinado: BRASIL, BAHIA: Abaíra, 17.I.2003, fl., L.R. Senna et al. 87 (HUEFS). Rio de Contas, 3.III.1994, fl., C.M. Atkins et al. 14785 (SPF).

Ocorre da Guiana até Argentina, Uruguai e Brasil (Oliveira \& Valls 2001). No Brasil ocorre em todas as regiões (Flora do Brasil 2020). Paspalum maculosum caracteriza-se pelos rizomas arqueados cobertos de catáfilos e pela gluma superior e a lema inferior papilosos e com máculas douradas; porém, este último caráter é variável e ocasionalmente as espiguetas não têm máculas (Zuloaga et al. 2004). Na Chapada Diamantina é encontrado em áreas de campo rupestre.

Paspalum madorense Renvoize, Kew Bull. 39:179. 1984.

(Fig. 4 C; Figs. 8 H-J)

Plantas perenes, rizomatosas, ca. $40 \mathrm{~cm}$ alt. Colmos com 9-15 nós, invaginados. Folhas distribuídas ao longo do colmo; bainhas não desfiadas, não infladas, glabras, as inferiores glabras, margens glabras; lígula ca $0,5 \mathrm{~mm}$ compr.; aurículas ausentes; lâminas $8-11,5 \times 3-4 \mathrm{~cm}$, lineares, planas, glabras, base truncada. Inflorescências terminais 4-5,5 cm compr., 2(3) racemos subconjugados; inflorescências axilares ausentes; ráquis sem alas laterais. Espiguetas 2,2-2,5 x 1-1,2 mm, solitárias, pediceladas, elípticas, obtusas, não apiculadas, esverdeadas a paleáceas, sem máculas; gluma inferior ausente; gluma superior 2,22,5 mm compr., 3-nervada, glabra, não papilosas, não ciliada nas margens; lema inferior 2-2,2 $\mathrm{mm}$ compr., 3-nervado, glabro, não hialino, não papiloso, margens glabras; antécio inferior estéril, pálea ausente; antécio superior 2-2,2 x 1-1,2 mm, não estipitado, elíptico, ápice obtuso, glabro, liso, estramíneo. Cariopse não vista.

Material examinado: BRASIL, BAHIA: Morro do Chapéu, 6.V.2007, fl., R.P. Oliveira et al. 1337 (HUEFS).

Endêmica do Brasil, exclusiva do estado da Bahia (Flora do Brasil 2020). Paspalum madorense destaca-se pelas espiguetas obtusas solitárias e colmo 'invaginado', ou seja, as bainhas foliares circundam conspicuamente $o$ eixo do caule. A região de diferenciação entre bainha e lâmina, inclusive a lígula, não são muito bem definidas nessa espécie, tornando pouco evidentes tais estruturas. $\mathrm{Na}$ Chapada Diamantina é encontrado próximo a leito de rios.

Paspalum mandiocanum Trin, Gram. Panic. 113. 1826. (Fig. 4 B; Fig. 8 K)

Plantas perenes, cespitosas, ca. $50 \mathrm{~cm}$ alt. Colmos com 8-9 nós, não invaginados. Folhas distribuídas ao longo do colmo; bainhas não desfiadas, não infladas, glabras, as inferiores glabras, margens ciliadas; lígula ca. $1 \mathrm{~mm}$ compr.; aurículas ausentes; lâminas 4,5-8 x 1-1,5 cm, lanceoladas, planas, glabras a esparsamente pilosas, base obtusa. Inflorescências terminais 5-6 cm compr., 1-5 racemos alternos; inflorescências axilares presentes; ráquis sem alas laterais. Espiguetas ca. 2 x 1,3 mm, pareadas, pediceladas, oval-elípticas, agudas, levemente apiculadas, esverdeadas, sem máculas; gluma inferior ausente; gluma superior ca. 1,5 mm compr., 5-nervada, glabra, não papilosa, não ciliada nas margens; lema inferior ca. $2 \mathrm{~mm}$ compr., 3-nervado, glabro, margens glabras, não hialino, não papiloso, margens glabras; antécio inferior estéril, pálea ausente; antécio superior 1,9 x 1,3 mm, não estipitado, oval, ápice agudo, glabro, papiloso, estramíneo. Cariopse não vista.

Material examinado: BRASIL, BAHIA: Abaíra, 13.X.2012, fl., K.M. Pimenta et al. 540 (HUEFS).

Ocorre no Brasil, Paraguai, Argentina e Uruguai. No Brasil foi registrado nas regiões Centro-Oeste, Sudeste e Sul (Flora do Brasil 2020), sendo uma nova ocorrência para a região Nordeste. Paspalum mandiocanum que ocorre na Chapada Diamantina trata-se da var. subaequiglume I.L.Barreto, a qual caracteriza-se pela inflorescência com 1-5 ramos alternos, e gluma superior com $1 / 3$ do comprimento do antécio superior, enquanto a variedade típica desta espécie é caracterizada pela gluma superior e lema inferior do mesmo comprimento do antécio superior (Oliveira \& Valls 2001). O material analisado foi coletado em solo alagado entre afloramentos rochosos, sob sombra em áreas de floresta. 
Paspalum melanospermum Desv. ex Poir, Encycl. Suppl. 4. 315. 1816.

(Figs. 8 L-O)

Plantas anuais, cespitosas, ca. $35 \mathrm{~cm}$ alt. Colmos com 4-5 nós, não invaginados. Folhas distribuídas ao longo do colmo; bainhas não desfiadas, não infladas, glabras, as inferiores glabras, margens glabras; lígula ca. 1,5 mm compr.; aurículas ausentes; lâminas 2,5-9 x 3-6 $\mathrm{cm}$, lanceolada, planas, glabra a escabra, base truncada. Inflorescências terminais 3,5-4,5 cm compr., 2(3) racemos alternos; inflorescências axilares ausentes; ráquis sem alas laterais. Espiguetas 1,9-2 x 1,5 mm, pareadas, pediceladas, obovais, obtusas, não apiculadas, castanhas, sem máculas; gluma inferior ausente; gluma superior 1,6-1,9 mm compr., 5-nervada, glabra a levemente pilosa, com tricomas adpressos, não papilosas, não ciliada nas margens; lema inferior 1,9-2 mm compr., 5-nervado, glabro, não hialino, não papiloso, margens glabras; antécio inferior estéril, pálea ausente; antécio superior 1,8-2 x 1,5 mm, estipitado, oboval, ápice obtuso, glabro, levemente papiloso, castanho escuro. Cariopse não vista.

Material examinado: BRASIL. BAHIA: Rio de Contas, 19.VI.2005, fl., R. Dias-Melo et al. 277 (CEN).

Ocorre do México ao Brasil (Oliveira 2004) onde é registrada em todas as regiões do país (Flora do Brasil 2020). Paspalum melanospermum possui delimitação bem complicada, como evidenciado por Oliveira (2004), porém pode ser distinta das demais espécies da área de estudo pela espigueta com gluma superior e lema inferior não hialino, além do antécio superior castanho escuro e oboval. Na Chapada Diamantina é encontrado em áreas de campo rupestre.

Paspalum millegrana Schrad., Mant. 2: 175. 1824. (Fig. 4 D; Figs. 8 P-Q)

Plantas perenes, cespitosas, eretas, $100-200 \mathrm{~cm}$ alt. Colmos com ca. 5 nós, não invaginados. Folhas concentradas na base; bainhas não desfiadas, não infladas, glabras, as inferiores glabras, margens glabras; lígula 2-2,5 mm compr.; aurículas ausentes; lâminas 22,5-65 x 1-2 $\mathrm{cm}$, linear-lanceoladas, planas, glabras, base truncada. Inflorescências terminais 17-26,5 cm compr., (20)27-43 racemos alternos; inflorescências axilares ausentes; ráquis sem alas laterais. Espiguetas 1,8-2,1 x 1,5 mm, pareadas, pediceladas, obovais, obtusas, apiculadas, castanhas, às vezes vináceas, sem máculas; gluma inferior ausente; gluma superior 1,8-2,1 mm compr., 3-nervada, glabra, não papilosa, não ciliada nas margens; lema inferior ca. 1,8 mm compr., 3-nervado, glabro, não hialino, não papiloso, algo deprimido no centro, margens glabras; antécio inferior estéril, pálea ausente; antécio superior 1,8-2 x 1,5 mm, não estipitado, oboval, ápice obtuso, glabro, papiloso, estramíneo. Cariopse ca. 1,3 x 1, oboval, castanha.

Material examinado: BRASIL, BAHIA: Ibicoara, 9.V.1999, fl, L.A. Passos et al. 243 (ALCB, CEPEC).
Lençóis, 4.VI.1998, fl., R. Funch 76 (HUEFS). Marimbus, 14.XII.2002, fl., F. França et al. 3932 (HUEFS). Morro do Chapéu, 3.V.2007, fl., R.P. Oliveira \& G.H. Rua 1243 (HUEFS); 19.II.2012, fl., K.M. Pimenta \& R.P. Oliveira 326 (HUEFS).

Ocorre na América Central e Antilhas até o Brasil (Renvoize 1984), onde é conhecida em todas as regiões (Flora do Brasil 2020). Paspalum millegrana é comumente confundida com $P$. densum, porém diferencia-se pelo formato quadrangular da inflorescência (vs. piramidal em P. densum) (Barreto 1966, Renvoize 1984), e o número de ramos da inflorescência, menor de 50 (vs. 60 ou mais em $P$. densum). Foi verificado ainda que em P. millegrana o antécio apresenta-se totalmente coberto e o lema tem uma pequena depressão central, enquanto que em $P$. densum as espiguetas apresentam antécio superior visível e o lema é plano. Na Chapada Diamantina é encontrada em áreas alteradas, principalmente próximas a estradas, rodovias e borda de florestas.

Paspalum minarum Hack., Oesterr. Bot. Z. 51:235. 1901.

(Fig. 4 E; Figs. 8 R-U)

Plantas perenes, cespitosas, $30-50 \mathrm{~cm}$ alt. Colmos com 3-5 nós, não invaginados. Folhas concentradas na base; bainhas não desfiadas, não infladas, glabras ou pilosas, as inferiores glabras, margens pilosas; lígula $0,3-0,8 \mathrm{~mm}$ compr.; aurículas ausentes; lâminas 4,5-6,5 x 0,3-0,5 $\mathrm{cm}$, lineares, planas a convolutas, pilosas, base truncada. Inflorescências terminais 6,5-9,5 cm compr., 3-4 racemos alternos; inflorescências axilares ausentes; ráquis sem alas laterais. Espiguetas 1,8-1,9 x $1 \mathrm{~mm}$, solitárias, pediceladas, oblongas, obtusas, não apiculadas, verde com manchas vináceas; gluma inferior ausente; gluma superior 1,8-1,9 mm compr., 4-nervada, glabra, não papilosa, não ciliada nas margens; lema inferior 1,8-1,9 mm compr., 2-nervado, glabro, com uma mancha em forma de $\mathrm{V}$, não hialino, não papiloso, margens glabras; antécio inferior estéril, pálea ausente; antécio superior 1,5-1,8 x 0,8 mm, não estipitado, oblongo, ápice obtuso, glabro, liso, estramíneo. Cariopse ca. 1 x $0,7 \mathrm{~mm}$, oval, castanha.

Material examinado: BRASIL, BAHIA: Abaíra, 17.I.2003, fl., L.R. Senna et al. 79 (HUEFS). Morro do Chapéu, 6.V.2007, fl., R.P. Oliveira et al. 1344 (HUEFS). Palmeiras, 22.VIII.2009, fl., J.C. Brito \& J. Marques 147 (HUEFS). Rio de Contas, 4.VIII.2006, fl., R.M. Harley 55526 (HUEFS).

Endêmica do Brasil, ocorrendo nas regiões Nordeste, Centro-Oeste e Sudeste (Flora do Brasil 2020). Paspalum minarum caracteriza-se pela sua inflorescência com 3-4 ramos alternos, com ráquis sem alas laterais e espiguetas solitárias, estas com uma mancha em forma de V no lema inferior. Esse caráter foi demonstrado em ilustrações por Renvoize (1984), embora não incluído nas descrições.

A espécie Paspalum brachytrichum Hack. está relacionada com $P$. minarum, por possuir sobreposição 
de caracteres quanto ao hábito e inflorescências que causam confusões na delimitação dessas espécies. Porém, $P$. brachytrichum pertence ao grupo informal Recta (Chase, inéd.) e diferencia-se principalmente pela ausência das nervuras na gluma superior (Hackel 1901). Endêmica dos campos rupestres sobre canga, na região do Quadrilátero Ferrífero (MG) (Viana \& Filgueiras 2008), P. brachytrichum é considerada criticamente em perigo (CR) segundo a Lista de Espécies ameaçadas de Extinção da Fundação Biodiversitas (Drummond et al. 2005), sendo indispensável o fornecimento de caracteres e ferramentas claras para a sua identificação.

$\mathrm{Na}$ área de estudos foram verificadas variações morfológicas bem definidas para Paspalum minarum, principalmente no hábito. No material K.M. Pimenta 330 (HUEFS), por exemplo, a planta é mais robusta com folhas largas, com 0,3-0,5 cm de largura; em K.M. Pimenta 294 e 327 a planta é mais delicada e as folhas mais estreitas, tornando-se filiformes, além de apresentar inflorescências com apenas 2 ramos. A delimitação desta espécie deve ser melhor avaliada. Na Chapada Diamantina é encontrado em áreas de cerrado e campo rupestre.

Paspalum molle Poir., Encycl. Suppl. 5:34. 1804.

(Figs. $8 \mathrm{~V}-\mathrm{Z}$ )

Plantas perenes, cespitosas, ca. $28 \mathrm{~cm}$ alt. Colmos com ca. 2 nós, não invaginados. Folhas concentradas na base; bainhas não desfiadas, não infladas, pilosas, as inferiores pilosas, margens glabras a pilosas; lígula 2-2,5 mm compr.; aurículas ausentes; lâminas 5,5-20 x 4-6 cm, linear, planas, levemente pilosas, base atenuada. Inflorescências terminais 1,5-2,2 cm compr., 2 racemos alternos; inflorescências axilares ausentes; ráquis sem alas laterais. Espiguetas 1,8-2 x 0,8-1 mm, pareadas, pediceladas, elípticas, agudas, não apiculadas, esverdeadas, sem máculas; gluma inferior ausente; gluma superior 1,8-0,8 mm compr., 5-nervada, pilosa, tricomas adpressos, não papilosa, não ciliada nas margens; lema inferior 1,6-1,8 mm compr., 3-nervado, levemente piloso, não hialino, não papiloso, margens glabras; antécio inferior estéril, pálea ausente; antécio superior 1,6-1,7 x 0,8-1 mm, não estipitado, elíptico, ápice agudo, glabro, liso, estramíneo. Cariopse não vista.

Material examinado: BRASIL, BAHIA: Andaraí, 18.XI. 2006, fl., M.F. Costa et al. 17 (HUEFS).

Ocorre no Sul dos Estados Unidos, América Central, Antilhas, Venezuela e Brasil (Renvoize 1984). No Brasil ocorre apenas na região Nordeste (Bahia e Pernambuco) (Flora do Brasil 2020). Paspalum molle chama atenção pelo seu pequeno porte e pelas longas lâminas foliares em relação à bainha. Pode ser confundida com $P$. corcovadense devido ao estreitamento na base da lâmina foliar, as quais tornam-se atenuadas. Porém em $P$. molle as espiguetas não ultrapassam $2 \mathrm{~mm}$ de comprimento, enquanto em $P$. corcovadense as espiguetas possuem mais de $2,5 \mathrm{~mm}$ de comprimento. Na Chapada Diamantina é encontrado em áreas de floresta.
Paspalum multicaule Poir., Encycl. Suppl. 4: 309.

1816.

(Figs. 9 A-D)

Plantas anuais, cespitosas, 7-18 cm alt. Colmos com ca. 2 nós, não invaginados. Folhas concentradas na base; bainhas não desfiadas, não infladas, glabras, as inferiores glabras, margens glabras; lígula ca. $1 \mathrm{~mm}$ compr.; aurículas ausentes; lâminas 3,5-7 x 0,1-0,2 cm, linear, planas, pilosas, base truncada. Inflorescências terminais 1,8-2,5 cm compr., 2 racemos conjugados; inflorescências axilares ausentes; ráquis sem alas laterais. Espiguetas 1,2 x $1 \mathrm{~mm}$, solitárias, pediceladas, orbiculares, obtusas, não apiculadas, esverdeadas com manchas vináceas; gluma inferior ausente; gluma superior ca. 1,2 mm compr., 3-nervada, pilosa, com tricomas globulares, não papilosa, não ciliada nas margens; lema inferior ca. 1,2 mm compr., 2-nervado, com tricomas globulares, não hialino, não papiloso, margens glabras; antécio inferior estéril, pálea ausente; antécio superior 1-1,2 x $1 \mathrm{~mm}$, não estipitado, suborbicular, ápice obtuso, glabro, levemente papiloso, estramíneo. Cariopse não vista. Material examinado: BRASIL, BAHIA: Canavieiras, 12.X.1998, fl., S.C. Sant'Ana et al. 714 (SP). Ibicoara, 13.X.2007, W. Guedes et al. 13836 (ALCB). Ibicoara, 13.X.2007, fl., M.L. Guedes et al. 13836 (ALCB). Morro do Chapéu, 18.II.1971, fl., H.S. Irwin et al. 32514 (UB). Mucugê, 05.II.1974, fl., R.M. Harley 16023 (CEN); 5.II.1974, fl., R.M. Harley 16023 (CEN, CEPEC).

Ocorre desde México, Bolívia, Trinidad até o Paraguai e Brasil (Oliveira \& Valls 2001), onde ocorre em todas as regiões, exceto no Sul (Flora do Brasil 2020). Paspalum multicaule pode ser confundida com $P$. clavuliferum, porém as espiguetas solitárias com tricomas globulares de $P$. multicaule as diferenciam, sendo que $P$. clavuliferum possui espiguetas pareadas com tricomas clavados. Comum em áreas com solo arenoso (Maciel et al. 2009), na Chapada Diamantina é encontrado em área de caatinga.

Paspalum nutans Lam., Tabl. Encycl. 1:175. 1791. (Fig. 4 F; Figs. 9 E, F)

Plantas perenes, decumbentes, $22-77 \mathrm{~cm}$ alt. Colmos com 4-5 nós, não invaginados. Folhas distribuídas ao longo do colmo; bainhas não desfiadas, não infladas, glabras, as inferiores glabras, margens glabras a pilosas; lígula ca. $1 \mathrm{~mm}$ compr.; aurículas ausentes; lâminas 4,5-12,5 x 0,8-1,5 cm, lanceoladas, planas, pilosas, base cuneada. Inflorescências terminais 3,5-5,5 cm compr., 1 racemo solitário; inflorescências axilares presentes; ráquis sem alas laterais. Espiguetas 1,9-2 x 1-1,2 mm, pareadas, pediceladas, elípticas, agudas, não apiculadas, esverdeadas, sem máculas; gluma inferior presente, geralmente reduzida; gluma superior 1,3-1,5 mm compr., 3-nervada, glabra, não papilosa, não ciliada nas margens; lema inferior 1,9-2 mm compr., 5-nervado, glabro, não hialino, não papiloso, margens glabras; antécio inferior estéril, pálea ausente; antécio superior 1,8-2 x 0,9-1,2 mm, não estipitado, elíptico, 
ápice agudo, glabro, papiloso, estramíneo. Cariopse não vista.

Material examinado: BRASIL, BAHIA: Andaraí, 13.X.2012, fl., K.M. Pimenta et al. 526 (HUEFS); 13.X.2012, fl., K.M. Pimenta et al 532 (HUEFS). Ibicoara, 12.X.2012, fl., K.M. Pimenta et al. 519 (HUEFS). Rio de Contas, fl., 18.X.12, R.P. Oliveira et al. 2180 (HUEF).

Ocorre de Honduras até o Brasil e Ilhas Maurício, na África (Oliveira \& Valls 2001). No Brasil ocorre em todas as regiões, exceto Centro-Oeste (Flora do Brasil 2020). Paspalum nutans caracteriza-se pelas inflorescências terminais e axilares com ramos solitários, espiguetas elípiticas com antécio papiloso, estramíneo. Chase (1929) menciona a ocorrência de até 4 ramos na inflorescência terminal, mas esse carácter não foi observado no material da Chapada Diamantina. Oliveira \& Valls (2001) afirmaram que a gluma inferior tem presença ocasional nas espiguetas desta espécie, mas nos materiais analisados durante esse trabalho observou-se a presença regular da gluma inferior, às vezes muito reduzida. Na Chapada Diamantina é encontrado em áreas de floresta, principalmente em solo úmido.

Paspalum oligostachyum Salzm. ex Steud., Syn. Pl. Glumac. 1:23. 1853.

(Figs. 9 G-J)

Plantas perenes, cespitosas, $45-80 \mathrm{~cm}$ alt. Colmos com ca. 3-4 nós, não invaginados. Folhas distribuídas ao longo do colmo; bainhas não desfiadas, não infladas, pilosas, as inferiores geralmente velutinas na base, margens pilosas; lígula 0,5-1 mm compr.; aurículas ausentes; lâminas 6,5-16 x 0,5-1 cm, lanceoladas, planas, pubescentes, base atenuada. Inflorescências terminais 8-11 cm compr., 4-6 racemos alternos; inflorescências axilares às vezes presentes; ráquis sem alas laterais. Espiguetas 1,8-2 x 1,3-1,5 mm, pareadas, pediceladas, obovais, agudas, não apiculadas, esverdeadas, sem máculas; gluma inferior ausente; gluma superior 1,8-2 $\mathrm{mm}$ compr., 5-nervada, pilosa, com tricomas adpressos, não papilosa, não ciliada nas margens; lema inferior 1,8$2 \mathrm{~mm}$ compr., 3-nervado, glabro a levemente piloso, não hialino, não papiloso, margens glabras; antécio inferior estéril, pálea ausente; antécio superior 1,5-1,9 x 1,3-1,5 $\mathrm{mm}$, não estipitado, oboval, ápice obtuso, glabro, levemente papiloso, estramíneo. Cariopse ca. 1,2 x $1 \mathrm{~mm}$, orbicular, castanha.

Material examinado: BRASIL, BAHIA: Abaíra, 27.V.2004, fl., G. Pereira-Silva et al. 9136 (HUEFS). Maracás, 27.II.2000, fl., R.P. Oliveira et al. 371 (HUEFS); 16.II.2004, fl., R.P. Oliveira et al. 1039 (HUEFS).

Ocorre em Trinidad, Guiana Francesa e Brasil (Renvoize 1984), onde é conhecida somente na região Nordeste (Bahia e Pernambuco) (Flora do Brasil 2020). Paspalum oligostachyum caracteriza-se pelas espiguetas pareadas, obovais e agudas com pubescência adpressa. É semelhante a $P$. corcovadense, devido à presença de estreitamento na base da lâmina foliar. Porém as espiguetas com até $2 \mathrm{~mm}$ de comprimento, obovais; antécios obovais, levemente papilosos; e cariopse orbicular, castanha de $P$. oligostachyum, se contrapõem às espiguetas com 2,5-2,8 $\mathrm{mm}$ de comprimento, elípticas, antécios elípticos, lisos e cariopse suborbicular, estramínea. $\mathrm{Na}$ Chapada Diamantina ocorre em áreas de floresta.

Paspalum paniculatum L., Syst. Nat., 10. 2:855. 1759.

Plantas perenes, curtamente rizomatosas, $60-73 \mathrm{~cm}$ compr. Colmos com ca. 4 nós, não invaginados. Folhas distribuídas ao longo do colmo; bainhas não desfiadas, não infladas, pilosas, as inferiores híspidas, margens híspidas; lígula 0,5-1 mm compr.; aurículas ausentes; lâminas 6-21 x 0,8-1,2 cm, linear-lanceoladas, planas, pilosas, base obtusa. Inflorescências terminais $6,5-8 \mathrm{~cm}$ compr., $10-14$ racemos alternos; inflorescências axilares ausentes; ráquis sem alas laterais. Espiguetas 1,3-1,5 x $1 \mathrm{~mm}$, pareadas, pediceladas, orbiculares, obtusas, levemente apiculadas, castanhas, sem máculas; gluma inferior ausente; gluma superior 1,3-1,5 mm compr., 3-nervada, pilosa, com tricomas velutinos, não papilosa, não ciliada nas margens; lema inferior 1,3-1,5 mm compr., 3-nervado, piloso, não hialino, não papiloso, margens glabras; antécio inferior estéril, pálea ausente; antécio superior 1,3-1,5 x $1 \mathrm{~mm}$, não estipitado, oboval, ápice obtuso, glabro, levemente papiloso, estramíneo. Cariopse não vista.

Material examinado: BRASIL, BAHIA: Morro do Chapéu, 3.V.2007, fl., R.P. Oliveira \& G.H. Rua 1242 (HUEFS). Mucugê, 14.X.2012, fl., K.M. Pimenta 558 (HUEFS).

Cosmopolita (Oliveira \& Valls 2001), no Brasil ocorre em todas as regiões (Flora do Brasil 2020). Paspalum paniculatum caracteriza-se pelo rizoma bem definido, bainhas inferiores híspidas, inflorescência com 10-14 ramos alternos, e espiguetas com 1,3-1,5 mm de comprimento orbiculares e pilosas. Na Chapada Diamantina ocorre em áreas de floresta, principalmente em regiões alteradas, como estradas e beira de trilhas.

Paspalum parviflorum Rhode ex Fluggé, Gram. Monogr. Paspalum. 98. 1810.

Plantas anuais, cespitosas, ca. $10 \mathrm{~cm}$ alt. Colmos com 3-4 nós, não invaginados. Folhas concentradas na base; bainhas não desfiadas, não infladas, glabras a pilosas, as inferiores geralmente glabras, margens glabras a pilosas; lígula ca. 2,5 mm compr.; aurículas ausentes; lâminas 3-5 x 0,15-0,3 cm, linear-lanceoladas, planas, hirsutas, base arredondada. Inflorescências terminais $0,8-1 \mathrm{~cm}$ compr., 3-4 racemos alternos; inflorescências axilares ausentes; ráquis sem alas laterais. Espiguetas 0,6-0,7 x 0,4 mm, solitárias, pediceladas, obovais, obtusas, não apiculadas, esverdeadas, sem máculas; gluma inferior ausente; gluma superior 2-nervada, glabra, não papilosa, não ciliada nas margens; lema inferior 0,6-0,7 mm compr., 2-nervado, glabro, hialino, não papiloso, margens glabras; antécio inferior estéril, pálea ausente; antécio superior 0,6-0,7 x 
0,4 mm, não estipitado, oboval, ápice obtuso, glabro, liso, estramíneo. Cariopse não vista.

Material examinado: BRASIL, BAHIA: Canavieiras, 12.X.1889, fl., S.C. Sant'Ana et al. 705 (HUEFS). Morro do Chapéu, 20.IX.1985, fl., G.C.P. Pinto 82 (CEPEC).

Ocorre desde o Panamá e Porto Rico até Brasil e Bolívia (Zuloaga \& Morrone 2005). No Brasil, ocorre nas regiões Norte, Nordeste e Centro-Oeste (Flora do Brasil 2020). Paspalum parviflorum caracteriza-se pelas diminutas espiguetas com até $0,7 \mathrm{~mm}$ de comprimento, solitárias, em pedicelos achatados, gluma superior e lema inferior 2-nervados e hialinos. Pode ser confundida com $P$. multicaule, porém esta espécie apresenta maior porte, lâminas foliares e espiguetas pilosas com tricomas globulares; enquanto que $P$. parviflorum apresenta menor porte, lâminas foliares densamente hirsutas e espiguetas glabras. Na Chapada Diamantina ocorre em área de campo rupestre.

Paspalum pilosum Lam., Tabl. Encycl. 1:175. 1791. (Fig. 4 G; Figs. 9 K-N)

Plantas perenes, cespitosas, 40-100 cm alt. Colmos com 5-7 nós, não invaginados. Folhas distribuídas ao longo do colmo; bainhas não desfiadas, não infladas, pilosas, as inferiores pilosas, margens ciliadas; lígula 1,5-2,5 mm compr.; aurículas ausentes; lâminas $13-28$ x 7-8 cm, linear-lanceoladas, planas, pilosas, base arredondada. Inflorescências terminais $10-13 \mathrm{~cm}$ compr., 1 racemo solitário; inflorescências axilares presentes; ráquis sem alas laterais. Espiguetas 2,8-3 x 1,5 mm, pareadas, pediceladas, elípticas, agudas, apiculadas, esverdeadas, sem máculas; gluma inferior presente; gluma superior 2,5-2,8 mm compr., 5-nervada, glabra, não papilosa, não ciliada nas margens; lema inferior 2,8-3 mm compr., 3-nervado, glabro, não hialino, não papiloso, margens glabras; antécio inferior raramente estaminado, pálea presente; antécio superior 2,2-2,5 x 1,2 mm, não estipitado, elíptico, ápice agudo, glabro, papiloso, estramíneo. Cariopse não vista.

Material examinado: BRASIL, BAHIA: Abaíra, 17.I.2003, fl., L.R. Senna et al. 86 (HUEFS); 13.X.2012, fl., K.M. Pimenta et al. 527 (HUEFS). Lençóis, 4.VI.1998, fl., R. Funch 70 (HUEFS); 28.XI.1998, fl., R.P. Oliveira \& D.S. Carneiro 149 (HUEFS). Mucugê, 1.X.2011, fl., K.M. Pimenta \& C. Silva 283 (HUEFS).

Ocorre da América Central até a Bolívia e Brasil (Renvoize 1984), onde é conhecida de todas as regiões do país (Flora do Brasil 2020). Paspalum pilosum é reconhecido pela inflorescência com um ramo solitário de 10-13 cm de comprimento, com inflorescências axilares, e pela presença de gluma inferior e pálea no antécio inferior. $\mathrm{Na}$ Chapada Diamantina é encontrado em áreas de floresta, principalemente regiões alteradas como estradas e trilhas.

Paspalum aff. planum Hack., Bull. Herb. Boissier. 2. 7:448. 1907.
Plantas perenes, cespitosas, $30-90 \mathrm{~cm}$ alt. Colmos com ca. 3 nós, não invaginados. Folhas concentradas na base; bainhas não desfiadas, não infladas, pilosas, as inferiores pilosas, margens glabras; lígula 2-3 mm compr.; aurículas ausentes; lâminas 10-30 x 0,5-1 cm, lineares, planas, pilosas em ambas as faces, base truncada. Inflorescências terminais 4-10 cm compr., 4-8 racemos alternos; inflorescências axilares ausentes; ráquis sem alas laterais. Espiguetas 3-4 x 1,8-2 mm, pareadas, pediceladas, elípticas, apiculadas, marrons, às vezes com manchas vináceas; gluma inferior ausente; gluma superior 3-47 mm compr., 3-nervada, glabra, não papilosa, não ciliada nas margens; lema inferior 3-4 mm compr., 3-nervado, glabro, não hialino, não papiloso, margens glabras; antécio inferior estéril, pálea ausente; antécio superior 0,4-0,8 x 1,7-1,9 mm, não estipitado, oval, ápice agudo, glabro, papiloso, estramíneo. Cariopse não vista.

Material examinado: BRASIL, BAHIA: Mucugê, 12.II.1994, fl., F.O. Zuloaga et al. 4799 (SI).

Ocorre no Paraguai e Brasil (Zuloaga \& Morrone 2005), onde é conhecida na Bahia e Minas Gerais (Flora do Brasil 2020). Paspalum planum é reconhecido pela inflorescência com 4-8 ramos, sem inflorescências axilares, e espiguetas maiores de $3 \mathrm{~mm}$ de comprimento; o material analisado apresenta espiguetas menores que as de materiais estrangeiros, e sua delimitação à nível específico deve ser ainda avaliada. Pode ser diferenciado de $P$. rupium pelas espiguetas mais largas (1,8-2 mm vs. 1-1,2 mm em $P$. rupium) e pela ausência de bainhas velutinas.

Paspalum plenum Chase, Contr. U.S. Natl. Herb. 28:202. 1929.

(Figs. 9 O-S)

Plantas perenes, cespitosas, 200-250 cm alt. Colmos com ca. 3 nós, não invaginados. Folhas concentradas na base; bainhas não desfiadas, não infladas, glabras, as inferiores glabras, margens glabras; lígula 1-2 mm compr.; aurículas ausentes; lâminas 50-65 x 2,5 cm, linearlanceoladas, planas, escabras na face abaxial, glabras na face adaxial, base truncada. Inflorescências terminais 40$43 \mathrm{~cm}$ compr., 100-130 racemos alternos; inflorescências axilares ausentes; ráquis sem alas laterais. Espiguetas 2,5-2,8 x 1,5-1,8 mm, pareadas, pediceladas, elípticolanceoladas, agudas, apiculadas, esverdeadas, às vezes com manchas vináceas; gluma inferior ausente; gluma superior 2,4-2,7 mm compr., 3-nervada, glabra, não papilosa, não ciliada nas margens; lema inferior 2,5-2,8 mm compr., 3-nervado, glabro, hialino, não papiloso, margens glabras; antécio inferior estéril, pálea ausente; antécio superior 2,32,5 x 1,3-1,5 mm, não estipitado, elíptico a oboval, ápice agudo, glabro, papiloso, estramíneo. Cariopse não vista.

Material examinado: BRASIL, BAHIA: Ibicoara, 1.II.1974, fl., R.M. Harley 15819 (CEPEC). Rio de Contas, 1.II.1997, fl., E. Saar et al. 4831 (CEPEC, HUEFS).

Ocorre no México, Costa Rica, Colômbia, Paraguai, Bolívia, Brasil e Argentina (Oliveira \& Valls 2001). No 
Brasil ocorre em todas as regiões, sendo uma nova ocorrência para o Nordeste (Flora do Brasil 2020). Paspalum plenum caracteriza-se pela sua inflorescência piramidal com até 130 ramos. Muito semelhante a $P$. intermedium Munro ex Morong, sendo muitas vezes confundidas nas identificações. Estas espécies podem ser diferenciadas pelas espiguetas com a gluma superior não ultrapassando o antécio em $P$. plenum, como ocorre em P. intermedium, e também pela base da planta, com bainhas comprimidas dispostas em forma de leque em $P$. intermedium (Zuloaga \& Morrone 2005). Na Chapada Diamantina ocorre em áreas de cerrado.

Paspalum polyphyllum Nees ex Trin., Gram. Panic. 114. 1826.

$$
\text { (Fig. } 4 \text { H; Fig. } 9 \text { T) }
$$

Plantas perenes, cespitosas, $30-50 \mathrm{~cm}$ alt. Colmos com ca. 12 nós, não invaginados. Folhas distribuídas ao longo do colmo; bainhas não desfiadas, não infladas, pilosas, as inferiores glabras a pilosas, margens glabras; lígula 0,5$1 \mathrm{~mm}$ compr.; aurículas ausentes; lâminas 3-7 x 0,2-0,6 $\mathrm{cm}$, linear-lanceoladas, planas, pilosas, base arredondada. Inflorescências terminais 3,5-5 cm compr., (1)2-3 racemos alternos; inflorescências axilares ausentes; ráquis com alas laterais estreitas, ca. 1,2 mm larg. Espiguetas 2,2-2,5 x 1,2-1,5 mm, pareadas, pediceladas, elípticas, agudas, não apiculadas, paleáceas a esverdeadas, sem máculas; gluma inferior ausente; gluma superior 2,2-2,5 x 1,2-1,5 mm compr., 3-nervada, densamente pilosa, com tricomas adpressos, não papilosas, longamente ciliada nas margens; lema inferior 2-2,2 mm compr., 3-nervado, piloso apenas no ápice, não hialino, não papiloso, margens glabras; antécio inferior estéril, pálea ausente; antécio superior 2,1-2,5 x $0,8 \mathrm{~mm}$, não estipitado, elíptico, ápice agudo, glabro, liso, estramíneo. Cariopse não vista.

Material examinado: BRASIL, BAHIA: Andaraí, 13.X.2012, fl., K.M. Pimenta et al. 535 (HUEFS). Mucugê, 1.X.2011, fl., K.M. Pimenta \& C. Silva 284 (HUEFS). Palmeiras, 5.III.1997, fl., A.A. Conceição 424 (SPF). Rio de Contas, 14.XI.1998, fl., R.P. Oliveira et al. 124 (HUEFS).

Ocorre na Argentina, Paraguai, Uruguai, Bolívia e Brasil (Oliveira \& Valls 2001). No Brasil, ocorre em todas as regiões do país, exceto no Norte (Flora do Brasil 2020). Paspalum polyphyllum é caracterizado pelas ráquis das inflorescências com alas laterais, espiguetas densamente pilosas e com mais de $2 \mathrm{~mm}$ de comprimento, com longos tricomas nas margens e até $4 \mathrm{~mm}$ de comprimento. É uma espécie com ampla variação morfológica, às vezes referidas como "fases" morfológicas (Denham et al. 2002).

Muito semelhante à Paspalum bicilium Mez, as quais já estiveram sinonimizadas sob P. polyphyllum (Denham et al. 2002). Porém diferem por P. bicilium apresentar colmos escandentes e bastante ramificados na base, espiguetas de até $2 \mathrm{~mm}$ de comprimento, e dois tricomas maiores e divergentes na gluma superior, chegando a medir até $8 \mathrm{~mm}$ de comprimento. Além disso, P. bicilium ocorre em margens de cursos d'água, no interior de matas de galeria no bioma Cerrado (Silva 2013). Por outro lado, P. polyphyllum ocorre em ambientes savânicos ou campestres e apresenta maiores dimensões da espigueta e da lâmina foliar, hábito ereto, colmos rizomatosos, mais frequentemente, sem ramificação ou, mais raro, com ramificação cimosa abundante (Silva 2013). Na Chapada Diamantina ocore em áreas de caatinga e campo rupestre.

Paspalum pumilum Nees, Fl. Bras. Enum. Pl. 2:52. 1829.

(Figs. 5 A, B; Figs. 10 A-E)

Plantas perenes, cespitosas, 7-30 cm alt. Colmos com 2-3 nós, não invaginados. Folhas concentradas na base; bainhas não desfiadas, não infladas, glabras a pilosas, as inferiores glabras a pilosas, margens pilosas; lígula $0,1-$ $0,5 \mathrm{~mm}$ compr.; aurículas ausentes; lâminas 1,5-11,5 x 0,3-1 cm, lineares a linear-lanceoladas, planas, glabras a pilosas, base arredondada. Inflorescências terminais 1,4$4 \mathrm{~cm}$ compr., 2 racemos subconjugados; inflorescências axilares ausentes; ráquis sem alas laterais. Espiguetas 1,52,2 x 0,9-1 mm, solitárias, pediceladas, elípticas, agudas, não apiculadas, esverdeadas, sem máculas; gluma inferior raramente presente, reduzida; gluma superior 1,5-1,8 mm compr., 5-nervada, glabra, não papilosa, não ciliada nas margens; lema inferior 1,4-1,7 mm compr., 3(5)-nervado, glabro, não hialino, não papiloso, margens glabras; antécio inferior estéril, pálea ausente; antécio superior 1,4-1,7 x 0,7-0,8 mm, não estipitado, oval-elíptico, ápice agudo, glabro, levemente papiloso, estramíneo. Cariopse não vista. Material examinado: BRASIL, BAHIA: Andaraí, 12.X.2012, fl., K.M. Pimenta et al. 518 (HUEFS); 13.X.2012, fl., K.M. Pimenta 529 (HUEFS). Mucugê, 1.X.2011, fl., K.M. Pimenta \& C. Silva 287 (HUEFS).

Ocorre nas Antilhas e América do Sul (Oliveira \& Valls 2001). No Brasil ocorre em todas as regiões (Flora do Brasil 2020). Paspalum pumilum caracteriza-se pelo porte pequeno, com folhas pilosas, inflorescência terminal com dois ramos, subconjugados; espiguetas solitárias, glabras. Pode ser confundida com P. giuliettiae, porém esta espécie apresenta inflorescência axilar e entrenó dos ramos da inflorescência com 6-10 $\mathrm{mm}$ de comprimento (Pimenta et al. 2013).

As amostras analisadas da Chapada Diamantina podem ser organizadas em dois morfotipos. Nos materiais K.M. Pimenta 287, 523 e 525 as plantas apresentaram hábito ereto, longas lâminas foliares até $11,7 \mathrm{~cm}$ de comprimento, as quais são lineares, e espiguetas com até $1,8 \mathrm{~mm}$ de comprimento. Os materiais K.M. Pimenta 518 e 529 são mais similares ao que é típico da espécie, com hábito mais rasteiro em forma de roseta, lâminas foliares curtas com até $3 \mathrm{~cm}$ de comprimento, linear-lanceoladas, e espiguetas com até $1,5 \mathrm{~mm}$ de comprimento. Na Chapada Diamantina é encontrado em áreas de floresta, principalmente em solos úmidos. 

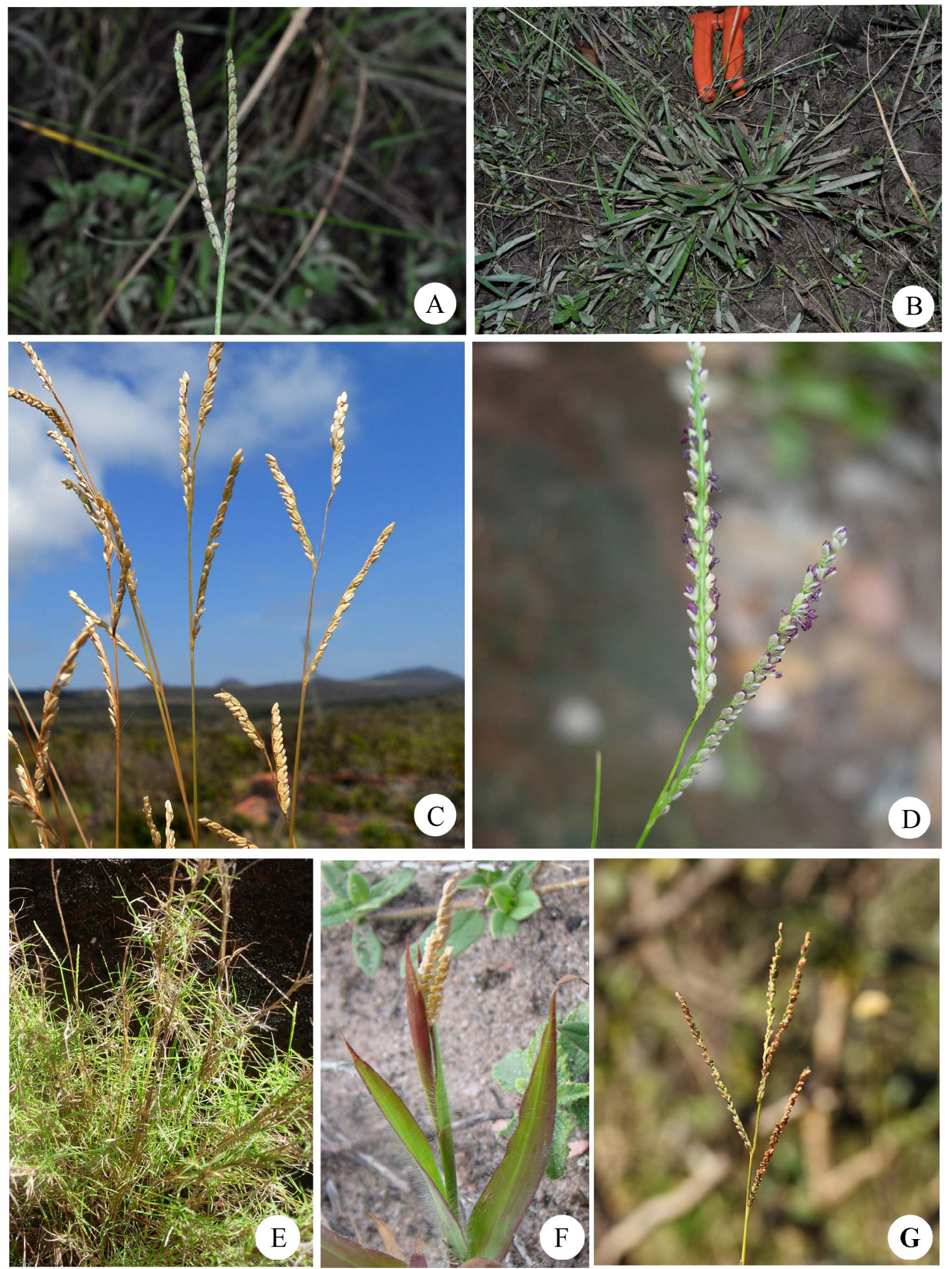

Figs. 5A-B. Paspalum pumilum: A. Inflorescência; B. Hábito; C. P. rupium, Inflorescência; D-E: P. scalare; D. Inflorescência; E. Hábito; F. P. scutatum, Inflorescência; G. P. trichostomum, inflorescência. Fotos: Figs. A, B, D, E (G.H. Rua); Figs. C, F (K.M. Pimenta); Fig. G (R. C. Oliveira). 


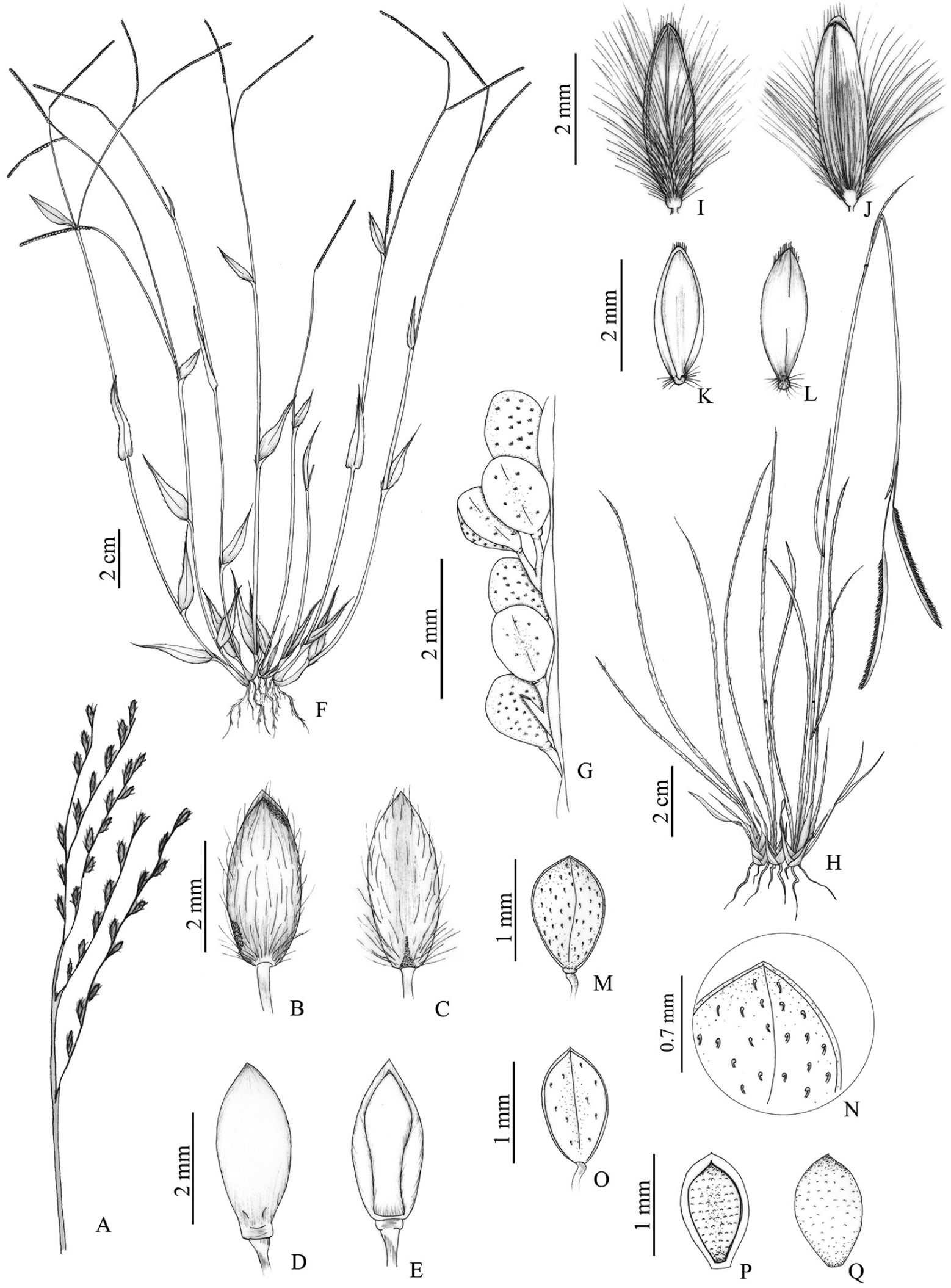

Figs. 6A-E. Paspalum ammodes: A. Inflorescência; B. Espigueta vista da gluma superior; C. Espigueta vista do lema inferior; D. Antécio superior visto do lema; E. Antécio superior visto da pálea; F-G: P. arenarium: F. Hábito; G. Espiguetas no racemo; H-L: P. carinatum; H. Hábito; I. Espigueta vista da gluma superior; J. Espigueta vista do lema inferior; K. Antécio superior visto da pálea; L. Antécio superior visto do lema; M-Q: P. clavuliferum: M. Espigueta vista da gluma superior; N. Tricomas clavados na gluma superior; O. Espigueta vista do lema inferior; P. Antécio superior visto da pálea; Q. Antécio superior visto do lema. Ilustração: K.M. Pimenta. 

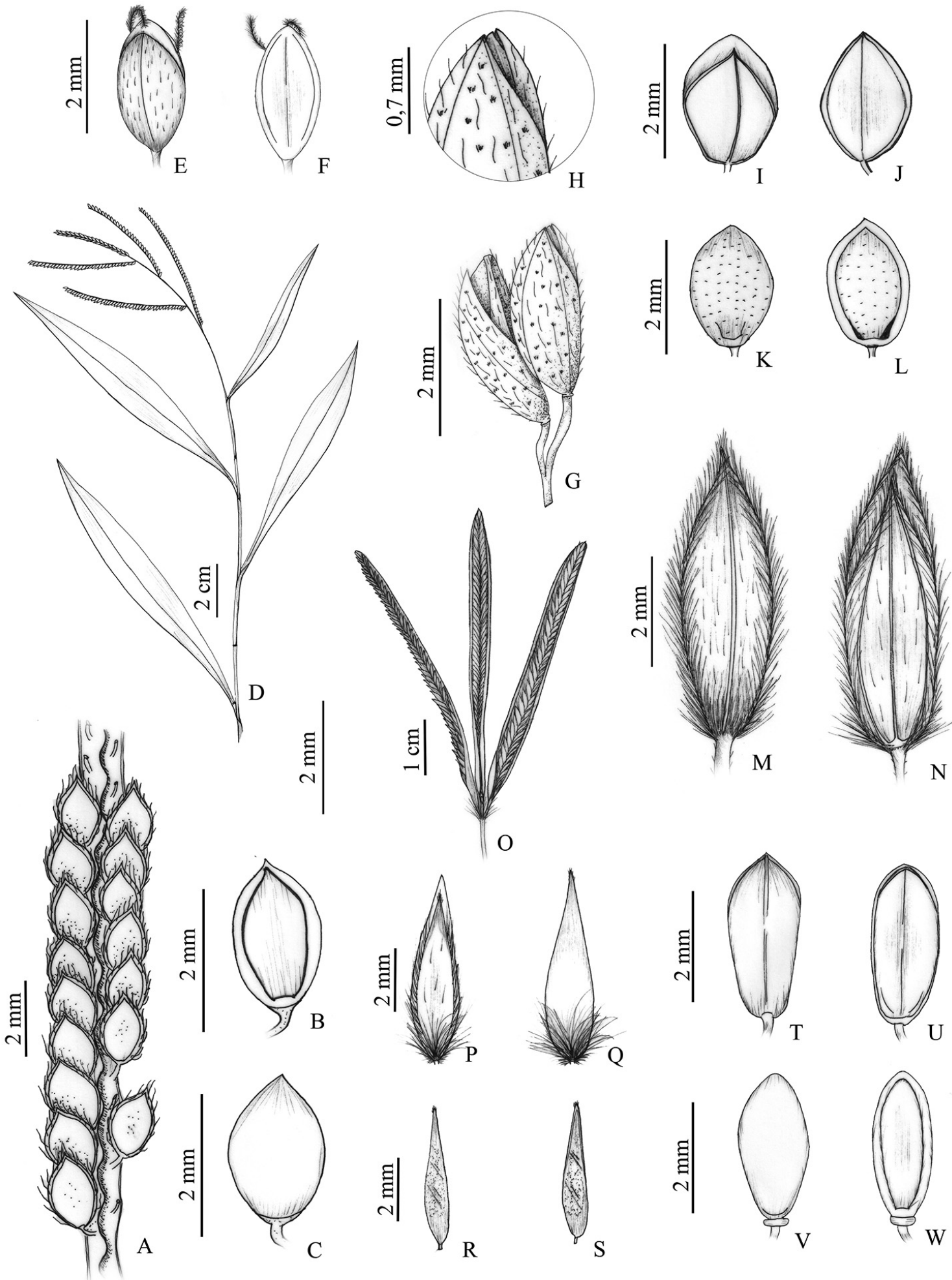

Figs. 7A-C. P. conjugatum: A. Ampliação da ráquis da inflorescência com as espiguetas; B. Antécio superior visto da pálea; C. Antécio superior visto do lema; D-F. P. corcovadense: D. Hábito; E. Espigueta vista da gluma superior; F. Espigueta vista do lema inferior; G-H. P. coryphaeum: G. Par de espiguetas; H. Detalhe dos tricomas vista da gluma superior; I-L. P. densum; I. Espigueta vista da gluma superior; J. Espigueta vista do lema inferior; K. Antécio superior visto do lema; L. Antécio superior visto da pálea; M-N. P. erianthum: M. Espigueta vista da gluma superior; N. Espigueta vista do lema inferior; O-S. P. lanciflorum: O. Inflorescência; P. Espigueta vista da gluma superior; Q. Espigueta vista do lema inferior; R. Antécio superior visto do lema; S. Antécio superior visto da pálea; T-W. P. ligulare: T. Espigueta vista da gluma superior; U. Espigueta vista do lema inferior; V. Antécio superior visto do lema; W. Antécio superior visto da pálea. Ilustração: K.M. Pimenta. 

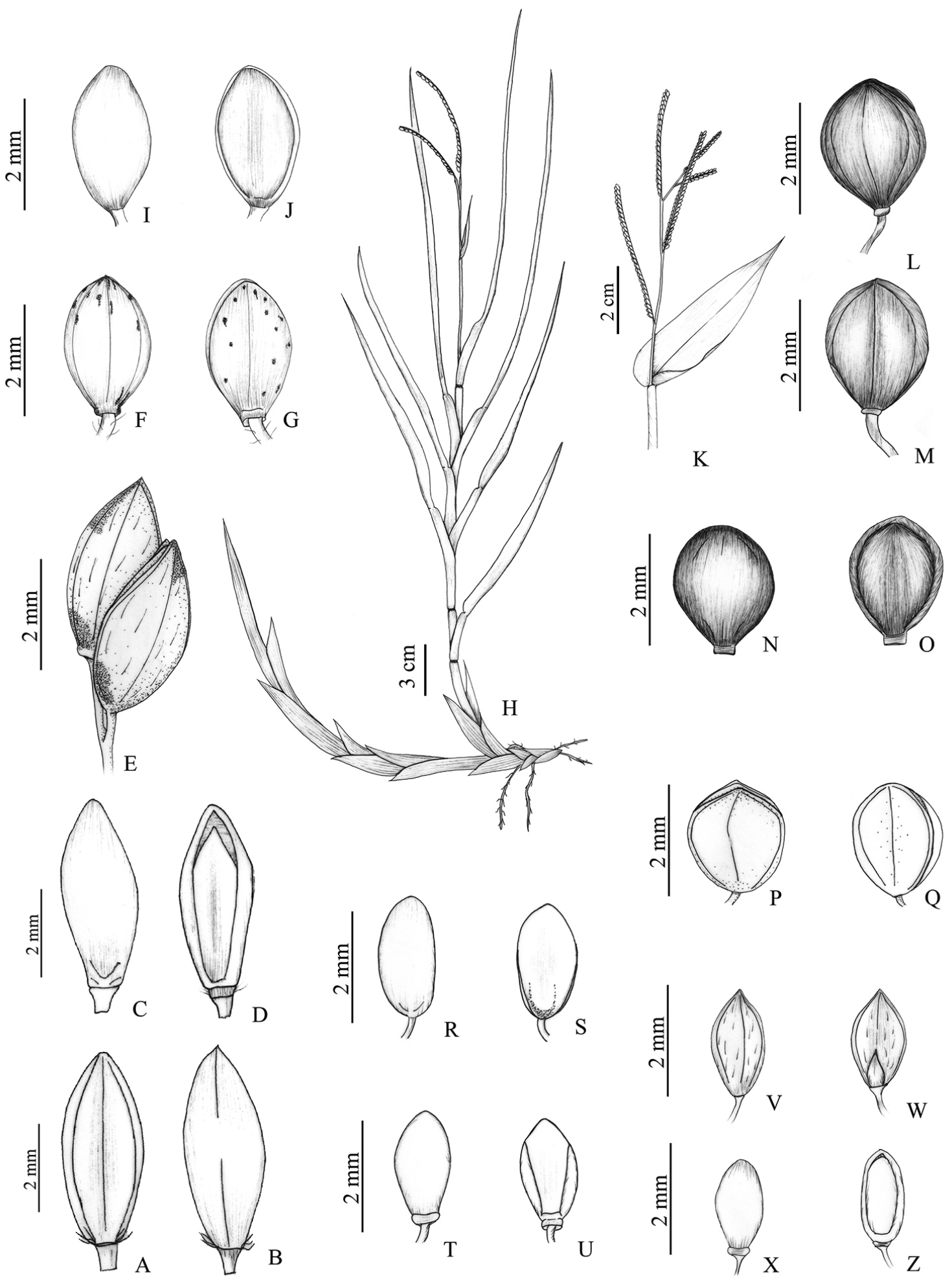
Paspalum repens Berg., Act. Helv. Phys-Math. 7. 129. 1772.

(Figs. 10 F-H)

Plantas perenes, aquáticas, ca. $50 \mathrm{~cm}$ alt. Colmos ca. 4-5 nós, não invaginados. Folhas distribuídas ao longo do colmo; bainhas não desfiadas, infladas, glabras, as inferiores glabras, margens glabras; lígula ca. $3 \mathrm{~mm}$ compr.; aurículas presentes; lâminas $25-30 \times 1 \mathrm{~cm}$, lanceoladas, planas, pilosas, base truncada. Inflorescências terminais ca. $17 \mathrm{~cm}$ compr., 30-54 racemos alternos; inflorescências axilares ausentes; ráquis com alas laterais, ca. 1,5 mm larg. Espiguetas 1,5-1,8 x 0,6-0,8 mm, solitárias, pediceladas, elípticas, agudas, apiculadas, esverdeadas a paleáceas, sem máculas; gluma inferior ausente; gluma superior 1,5-1,8 mm compr., 2-nervada, glabra, não papilosa, não ciliada nas margens; lema inferior 1,5-1,7 mm compr., 2-nervado, glabro, não hialino, não papiloso, margens glabras; antécio inferior estéril, pálea ausente; antécio superior 1,4-1,7 x 0,6-0,8 mm, não estipitado, elíptico, ápice agudo, glabro, levemente papiloso, estramíneo. Cariopse não vista.

Material examinado: BRASIL, BAHIA: Morro do Chapéu, 14.VI.1975, fl., Pereira \& Gusmão s.n. (ALCB 01853).

Ocorre dos Estados Unidos até a Argentina e Uruguai (Zuloaga \& Morrone 2005). No Brasil ocorre em todas as Regiões (Flora do Brasil 2020). Paspalum repens é a única espécie aquática dentre as espécies desse gênero ocorrentes na Chapada Diamantina (Chase 1929). É caracterizada principalmente pelas bainhas infladas, devido a cavidades aeríferas desenvolvidas (Aliscioni 2000), o que concede seu hábito flutuante.

Paspalum robustum (Hitchc. \& Chase) S. Denham, Novon. 16:331. 2006.

Plantas perenes, cespitosas, ca. $50 \mathrm{~cm}$ alt. Colmos com ca. 5 nós, não invaginados. Folhas distribuídas ao longo do colmo; bainhas não desfiadas, não infladas, glabras, as inferiores velutinas na base, margens glabras; lígula $0,1-$ $0,15 \mathrm{~mm}$ compr.; aurículas ausentes; lâminas $8-20 \times 0,4$ $\mathrm{cm}$, lineares, planas, densamente pilosas a hirsutas, base não truncada. Inflorescências terminais $9-11 \mathrm{~cm}$ compr., 1 racemo solitário; inflorescências axilares presentes; ráquis com alas laterais estreitas, ca. $3 \mathrm{~mm}$ larg. Espiguetas 4-4,2 x 1-1,5 mm, pareadas, pediceladas, elípticas, agudas, não apiculadas, esverdeadas, sem máculas; gluma inferior presente, reduzida; gluma superior 4-4,2 mm compr., 7-nervada, pilosa, com tricomas simples, não papilosa, não ciliada nas margens; lema inferior 3,5-3,7 mm compr., (4)3-nervado, sulcado, piloso, com tricomas simples, não hialino, não papiloso, margens glabras; antécio inferior estéril, pálea presente; antécio superior 3,8-4 x 0,8-1 mm, não estipitado, elíptico, ápice agudo, glabro, papiloso, estramíneo. Cariopse não vista.

Material examinado: BRASIL, BAHIA: Rio de Contas, 19.VI.2005, fl., R. Dias-Melo et al. 280 (CEN).
Ocorre desde a Costa Rica até o Brasil (Denham 2005). Representa um novo registro para a Bahia, antes citada no país apenas para Pernambuco (Flora do Brasil 2020). Paspalum robustum caracteriza-se pelas espiguetas pilosas com lema sulcado; estas são aparentemente solitárias, porém na realidade são pareadas com os pedicelos concrescentes com a ráquis aparentando uma única fileira (disposição "thrasyiode" [Burman 1985]), dispostas alternadamente com a gluma superior em posição abaxial e adaxial. A gluma inferior presente é reduzida e membranácea. É muito semelhante a $P$. foliiforme S. Denham, porém o material examinado da área de estudo possui ráquis com alas laterais estreitas, com 2-3 mm de largura, e espiguetas com gluma superior totalmente pilosa, contrapondo alas laterais de $7 \mathrm{~mm}$ de largura de $P$. foliiforme e gluma superior pilosa apenas no ápice (Denham 1985). Além disso, no material analisado foi verificada a presença de inflorescência axilar e gluma superior 7-nervada, divergindo da descrição de Maciel et al. (2009), que citou 3-nervada. Assim, mesmo aqui reconhecidos sob Paspalum robustum, esses materiais merecem maiores estudos, pela gluma superior ser totalmente pilosa e os nós glabros, como ocorre em P. foliiforme (Denham 2005). Na Chapada Diamantina é encontrada em áreas de caatinga e campo rupestre.

Paspalum rojasii Hack., Repert. Spec. Nov. Regni Veg. 7:369. 1909.

(Figs. 10 I-L)

Plantas perenes, cespitosas, $50-60 \mathrm{~cm}$ alt. Colmos 4-5 nós, não invaginados. Folhas distribuídas ao longo do colmo; bainhas não desfiadas, não infladas, pilosas, as inferiores geralmente pilosas na base, margens glabras a pilosas; lígula 1,5-2 $\mathrm{mm}$ compr.; aurículas ausentes; lâminas $10,5-18 \times 0,4-0,6 \mathrm{~cm}$, lineares, conduplicadas, hirsutas, base atenuada. Inflorescências terminais 7-15 cm compr., 2-3 racemos alternos; inflorescências axilares ausentes; ráquis sem alas laterais. Espiguetas 3,5 x 2-2,5 $\mathrm{mm}$, pareadas, pediceladas, elípticas a obovais, obtusas, não apiculadas, esverdeadas a castanhas, sem máculas; gluma inferior presente; gluma superior 3-3,3 mm compr., 3-nervada, glabra, não papilosa, não ciliadas nas margens; lema inferior 3,5 mm compr., 5-nervado, glabro, hialino no centro, não papiloso, margens glabras; antécio inferior estéril, pálea ausente; antécio superior 3-3,2 x 1,8-2 mm, não estipitado, elíptico a oboval, ápice obtuso, glabro, papiloso, castanho escuro. Cariopse 2,3 x 1,5 mm, oboval, castanha.

Material examinado: BRASIL, BAHIA: Morro do Chapéu, 5.V.2007, fl., R.P. Oliveira et al. 1331 (HUEFS). Piatã, 27.II.2009, fl., M.L. Guedes et al. 14570 (ALCB).

Ocorre no Paraguai, Bolívia e Brasil (Oliveira \& Valls 2008). No Brasil está presente em todas as regiões do país, exceto a região Norte (Flora do Brasil 2020). Paspalum rojasii diferencia-se das demais espécies perenes da área de estudo pela sua espigueta elíptica a oboval, obtusa, lema hialino no centro, e antécio castanho escuro. É uma 
espécie altamente polimórfica, formando um complexo (Oliveira 2004). No material M.L. Guedes et al. 14570, as espiguetas são mais obovais e os lemas inferiores são levemente plicados. Na Chapada Diamantina é encontrado em áreas de cerrado e ocasionalmente em campo rupestre, preferindo substrato arenoso (Oliveira 2004).

Paspalum rupium Renvoize, Kew Bull. 39:179. 1984. (Fig. 5 C; Figs. $10 \mathrm{M}-\mathrm{Q}$ )

Plantas perenes, rizomatosas, os rizomas curtos e grossos, $34-50 \mathrm{~cm}$ alt. Colmos 2-4 nós, não invaginados. Folhas concentradas na base; bainhas desfiadas na base cobrindo os rizomas, não infladas, as inferiores velutinas, margens pilosas; lígula $0,5-1,8 \mathrm{~mm}$ compr.; aurículas ausentes; lâminas $6-20 \times 2-2,5 \mathrm{~cm}$, planas a filiformes, convolutas, glabras, base truncada. Inflorescências terminais 3,5-9 cm compr., 2-4 racemos alternos; inflorescências axilares ausentes; ráquis com alas laterais, 1-1,5 $\mathrm{mm}$ larg. Espiguetas 2,5-2,9 x 1-1,2 mm, pareadas, pediceladas, elípticas, agudas, não apiculadas, esverdeadas, às vezes com manchas vináceas; gluma inferior ausente; gluma superior 2-2,9 mm compr., 3-nervada, glabra, não papilosa, não ciliadas nas margens; lema inferior 2,5-2,9 mm compr., 3-nervado, glabro, não hialino, não papiloso, margens glabras; antécio inferior estéril, pálea ausente; antécio superior 2,2-2,5 x 0,9-1,2 mm, não estipitado, elíptico, ápice obtuso, glabro, liso, estramíneo. Cariopse não vista. Material examinado: BRASIL. BAHIA: Mucugê, 14.II.2005, fl., R.M. Harley 1170 (HUEFS); 14.X.2012, fl., K.M. Pimenta et al. 551 (HUEFS). Palmeiras, 22.X.1999, fl., A.A. Conceição 613 (HUEFS).

Nativa do Brasil e endêmica do estado da Bahia (Flora do Brasil 2020). Paspalum rupium é reconhecido pelos rizomas curtos cobertos pelas bainhas inferiores velutinas. Dos materiais examinados, R.P. Oliveira. et al. 1348 (Morro do Chapéu), apresentou aspectos morfológicos um pouco distintos dos demais, com mais ramos nas inflorescências (até 21), e lâminas foliares lineares, planas, com $1 \mathrm{~cm}$ de largura, diferente do padrão geral encontrado na Chapada Diamantina, com lâminas foliares filiformes, convolutas, com 2-2,5 mm de largura. Na Chapada Diamantina é encontrado principalmente em áreas de cerrado e campo rupestre.

Paspalum scalare Trin., Sp. Gram. 3: t. 274.1829. (Figs. 5 D, E)

Plantas perenes, cespitosas, muito ramificadas, ca. 30 $\mathrm{cm}$ alt. Colmos com 10-20 nós, não invaginados. Folhas distribuídas ao longo do colmo; bainhas não desfiadas, não infladas, glabras a pilosas, as inferiores glabras a pilosas, margens densamente pilosas; lígula $0,5-1 \mathrm{~mm}$ compr.; aurículas ausentes; lâminas $0,5-4$ x 0,1 cm, lineares, planas, hirsutas, base truncada. Inflorescências terminais 2-3,5 cm compr., 1(5) racemos; inflorescências axilares ausentes; ráquis sem alas laterais. Espiguetas 1,2-1,5 x
0,5-0,8 mm, pareadas, pediceladas, elípticas, agudas, não apiculadas, esverdeadas, sem máculas; gluma inferior ausente; gluma superior 1,2-1,5 mm compr., 3-nervada, pilosa, com tricomas tuberculados, não papilosa, não ciliada nas margens; lema inferior 1,2-1,5 mm compr., 2-nervado, piloso, tricomas tuberculados, não hialino, não papiloso, margens glabras; antécio inferior estéril, pálea ausente; antécio superior 1,2-1,5 x 0,5-0,8 mm, não estipitado, elíptico, ápice obtuso, glabro, levemente papiloso, estramíneo. Cariopse não vista.

Material examinado: BRASIL, BAHIA: Rio de Contas, 22.VI.1929, fl., S.A. Mori et al. 12479 (CEPEC); Pico das Almas, 18.I.2003, fl., M.C. Ferreira et al. 1321 (HUEFS); 18.X.2012, fl., R.P. Oliveira et al. 2160, 2167 (HUEFS).

Esta espécie é endêmica do Brasil, ocorrendo nas regiões Nordeste, Centro-Oeste e Sudeste (Flora do Brasil 2020). Paspalum scalare caracteriza-se pelos colmos muito ramificados, com muitos nós, entre 10-20, e lâminas foliares patentes, formando ângulos de $90^{\circ}$ com o colmo. É semelhante a $P$. parviflorum, porém sua quantidade inferior de nós, 3-4, a diferencia de $P$. scalare, que apresenta 10-20 nós. Na Chapada Diamantina é encontrado principalmente em áreas de campo rupestre.

Paspalum scutatum Nees ex Trin., Gram. Panic. 105. 1826.

$$
\text { (Fig. } 5 \text { F; Figs. } 10 \text { R-U) }
$$

Plantas anuais, cespitosas, ca. $36 \mathrm{~cm}$ alt. Colmos com ca. 3 nós, não invaginados. Folhas distribuídas ao longo do colmo; bainhas não desfiadas, não infladas, pilosas, as inferiores geralmente híspidas, margens pilosas; lígula 2-3 mm compr.; aurículas ausentes; lâminas 3-7,5 x 0,4-0,6 $\mathrm{cm}$, lanceoladas, planas, pilosas a glabras, base truncada. Inflorescências terminais 3,7-5,5 cm compr., 2-3 racemos alternos; inflorescências axilares ausentes; ráquis sem alas laterais. Espiguetas 1,8-2 x 1,8-2 mm, pareadas, pediceladas, escudadas, agudas, apiculadas, paleáceas, sem máculas; gluma inferior ausente; gluma superior 1,8-2 mm compr., 5-nervada, glabra, não papilosa, não ciliadas nas margens; lema inferior 1,7-1,9 mm compr., nervuras não evidentes, glabro, não hialino, não papiloso, margens glabras; antécio inferior estéril, pálea ausente; antécio superior ca. 1,5 x 1,3 mm, não estipitado, oboval, ápice obtuso, glabro, liso, estramíneo. Cariopse não vista.

Material examinado: BRASIL, BAHIA: Lençóis, 27.IV.1978, fl., S.A. Mori et al. 10015 (CEPEC). Morro do Chapéu, 19.II.2012, fl., K.M. Pimenta \& R.P. Oliveira 304 (HUEFS).

Endêmica do Brasil ocorre somente na região Nordeste (Flora do Brasil 2020), exclusivamente associada ao semiárido. Paspalum scutatum caracteriza-se pelas espiguetas tipicamente em forma de escudo, e poderia realmente ser confundida com $P$. fimbriatum, porém esta espécie possui fímbrias que se prolongam da gluma superior, as quais não formam um escudo. Na Chapada Diamantina é encontrado em áreas de caatinga. 


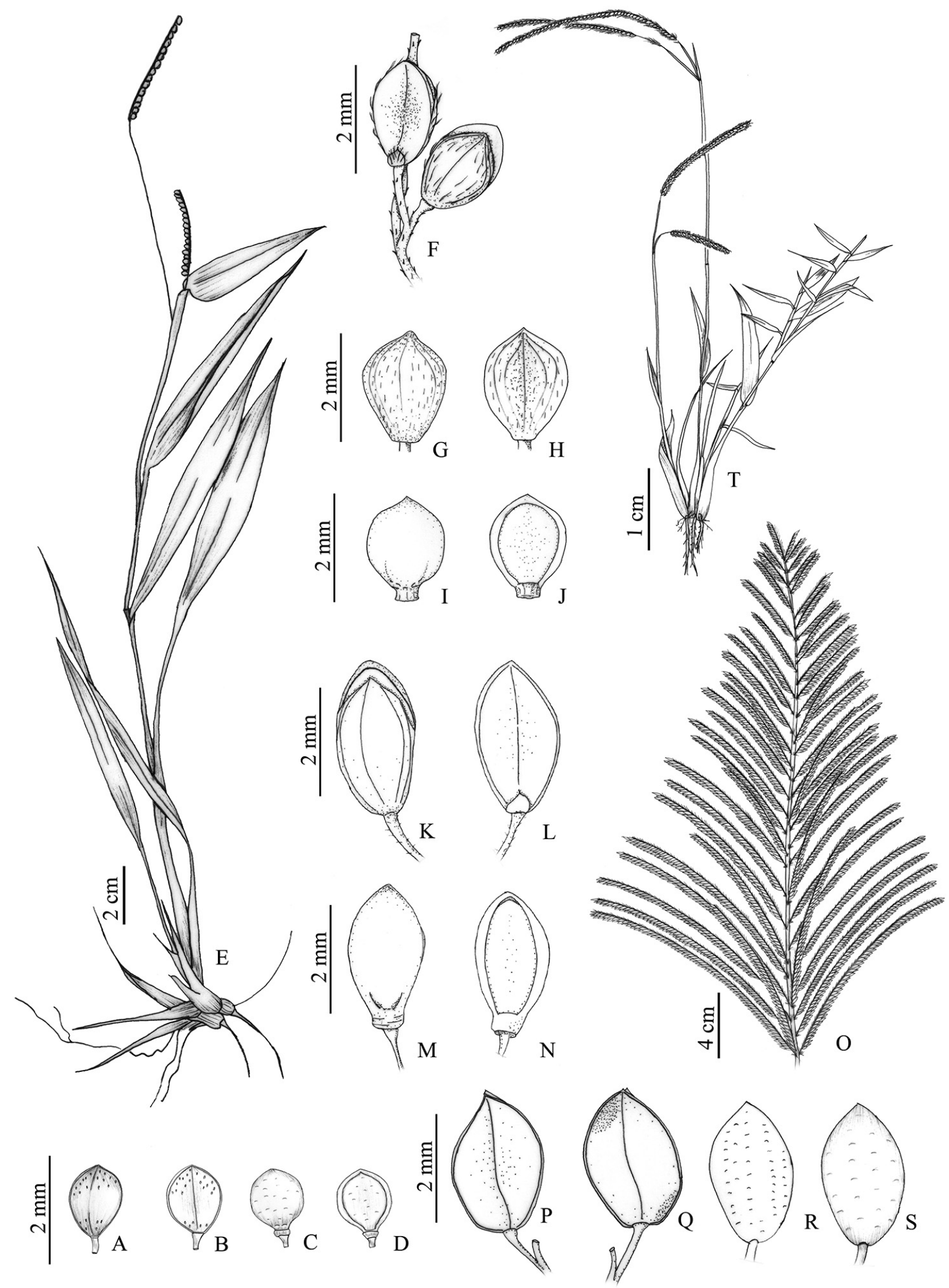

Figs. 9A-B. P. multicaule: A. Espigueta vista da gluma superior; B. Espigueta vista do lema inferior; C. Antécio superior visto do lema; D. Antécio superior visto da pálea; E-F. Paspalum nutans: E. Hábito; F. Par de espiguetas; G-J. P. oligostachyum: G. Espigueta vista da gluma superior; H. Espigueta vista do lema inferior; I. Antécio superior visto do lema; J. Antécio superior visto da pálea; K-N. P. pilosum: K. Espigueta vista da gluma superior; L. Espigueta vista da gluma inferior; M. Antécio superior visto do lema; N. Antécio superior visto da pálea; O-S. P. plenum: O. Inflorescência; P. Espigueta vista da gluma superior; Q. Espigueta vista do lema inferior; R. Antécio superior visto do lema; $\mathbf{S}$. Antécio superior visto superior da pálea; T. P. polyphyllum, hábito. Ilustração: K.M. Pimenta. 

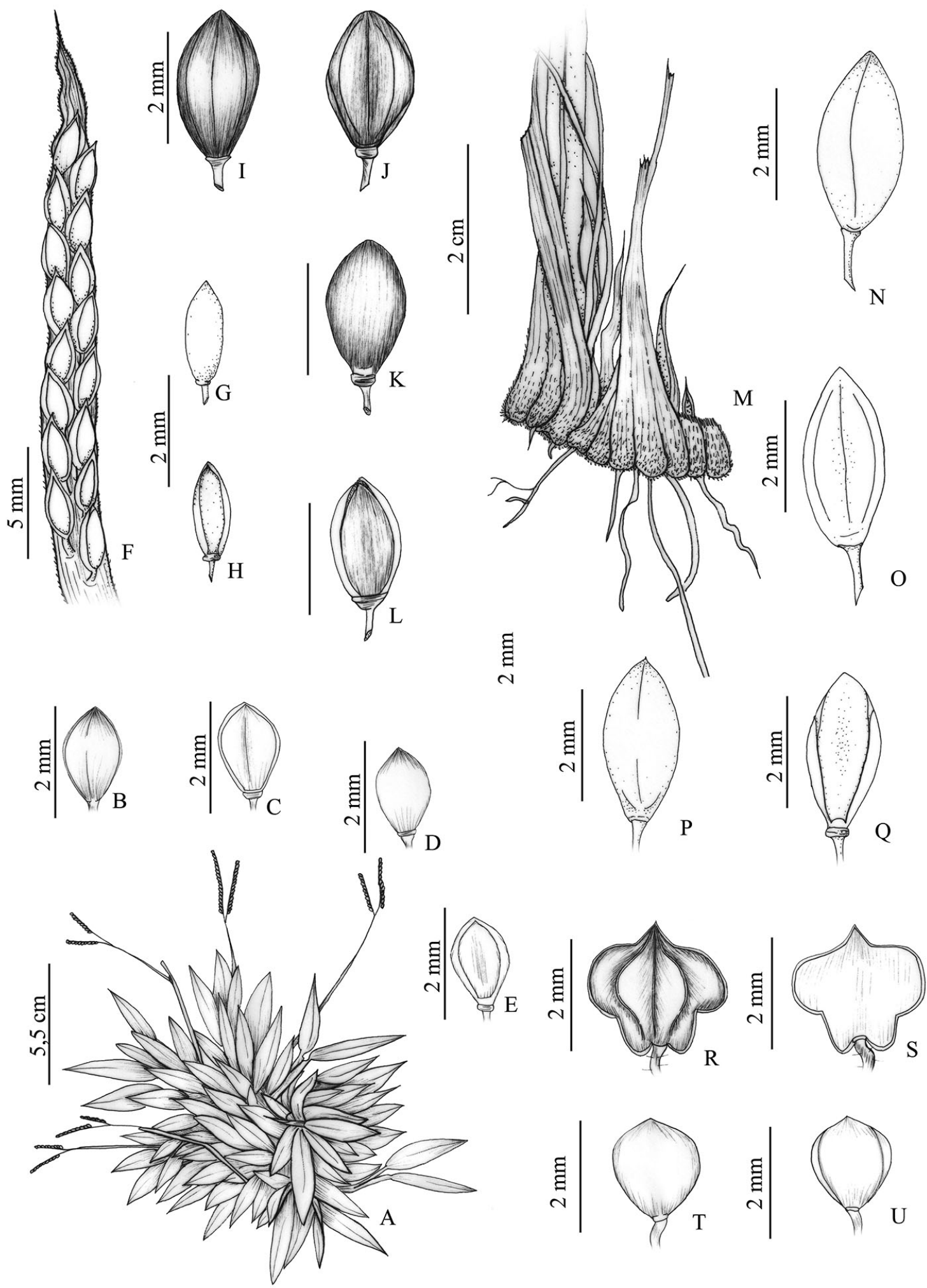

Figs. 10A-E. Paspalum pumilum; A. Hábito. B. Espigueta vista da gluma superior. C. Espigueta vista do lema inferior. D. Antécio superior visto do lema. E. Antécio superior visto da pálea. F-H: P. repens. F. Ramo da inflorescência com as espiguetas. G. Antécio superior visto do lema. H. Antécio superior visto da pálea. I-L: P. rojasii. I. Espigueta vista da gluma superior. J. Espigueta vista do lema inferior. K. Antécio superior visto do lema. L. Antécio superior visto da pálea. M-Q: P. rupium. M. Base da planta com o rizoma. N. Espigueta vista da gluma superior. O. Espigueta vista do lema inferior. P. Antécio superior visto do lema. Q. Antécio superior visto da pálea. R-U: P. scutatum. R. Espigueta vista da gluma superior. S. espigueta vista do lema inferior. T. Antécio superior visto do lema. U. Antécio superior visto da pálea. Ilustração: K.M. Pimenta. 
Paspalum trichostomum Hack., Oesterr. Bot. Z. 51:236. 1901.

(Fig. 5 G)

Plantas perenes, cespitosas, ca. $45 \mathrm{~cm}$ alt. Colmos com 2-3 nós, não invaginados. Folhas concentradas na base; bainhas desfiadas, não infladas, glabras a pilosa, as inferiores pilosas, margens pilosas; lígula ca. $0,5 \mathrm{~mm}$ compr.; aurículas ausentes; lâminas $14-16$ x 0,3-0,4 cm, lineares, planas, pilosas, base truncada. Inflorescências terminais 6-9 cm compr., 2-3 racemos alternos; inflorescências axilares ausentes; ráquis sem alas laterais. Espiguetas 2,9-3 x 1,8 mm, pareadas, pediceladas, elípticas, agudas, não apiculadas, esverdeadas a vináceas, sem máculas; gluma inferior ausente; gluma superior ca. 2,9 mm compr., 3-nervada, glabra, não papilosa, não ciliada nas margens; lema inferior ca. 2,9 mm compr., 5-nervado, glabro, não hialino, não papiloso, margens glabras; antécio inferior estéril, pálea ausente; antécio superior 2,8-2,7 x 1,5 mm, não estipitado, elíptico, ápice agudo, glabro, papiloso, castanho, estramíneo. Cariopse não vista.

Material examinado: BRASIL, BAHIA: Rio de contas, 05.III.1994, fl., N. Roque et al. s.n. (203428 HUEFS).

Endêmica do Brasil, ocorrendo nos estados de Goiás, Minas Gerais, Distrito Federal, Mato Grosso (Flora do Brasil 2020) e Bahia. Paspalum trichostomum compartilha com P. loefgrenii a base da planta com bainhas senescentes desfiadas, formando um emaranhado de folhas secas, e espiguetas com ápice agudo; porém podem ser distintas principalmente pela dimensão das lâminas foliares as quais em $P$. loefgrenii são longas com $25,5-53 \mathrm{~cm}$ de comprimento, enquanto que em $P$. trichostomum são curtas com 14-16 cm de comprimento.

\section{Paspalum sp.}

Plantas perenes, estoloníferas, $30-40 \mathrm{~cm}$ alt. Colmos com 3-4 nós, não invaginados. Folhas distribuídas ao longo do colmo; bainhas não desfiadas, não infladas, glabras, as inferiores pilosas, margens glabras; lígula 2,53,5 mm compr.; aurículas ausentes; lâminas 3,5-9 x 0,2$0,4 \mathrm{~cm}$, lineares, conduplicadas, glabras, base truncada. Inflorescências terminais 3,5-6 cm compr., 2-3 racemos alternos; inflorescências axilares ausentes; ráquis sem alas laterais. Espiguetas 2,5 x 1,5-1,8 mm, pareadas, pediceladas, elípticas a obovais, obtusas, apiculadas, esverdeadas a castanhas; gluma inferior ausente; gluma superior ca. 2,5 mm compr., 5-nervada, glabra, não papilosa; lema inferior ca. 2,4 mm compr., 5-nervado, glabro, hialino, não papiloso, margens glabras; antécio inferior estéril, pálea ausente; antécio superior 2,5 x 1,5-1,8 mm, não estipitado, elíptico a oboval, ápice obtuso, glabro, papiloso, castanho escuro. Cariopse não vista.

Material examinado: BRASIL, BAHIA: Morro do Chapéu, 19.II.2012, fl., K.M. Pimenta \& R.P. Oliveira 306 (HUEFS).
Essa espécie é provavelmente um dos integrantes do grupo informal Plicatula devido ao seu antécio castanho escuro. Relacionada a Paspalum melanospermum Desv. ex Poir, porém esta espécie é anual e cespitosa, com gluma superior e lema inferior não hialinos. Paspalum sp. possui rizomas longos, lígula bem desenvolvida, com até $3,5 \mathrm{~mm}$ de comprimento, além de gluma superior e lema inferior hialinos. Devido a tais caracteres difere das espécies conhecidas do grupo Plicatula, e pode corresponder a uma espécie nova, endêmica da Chapada Diamantina. Estudos mais detalhados estão em andamento para maior certificação sobre seu status. Na Chapada Diamantina é encontrado em áreas de caatinga, geralmente regiões degradadas.

\section{AGRADECIMENTOS}

Às agências financiadoras Conselho Nacional de Desenvolvimento Científico e Tecnológico, pelo apoio financeiro através dos programas PROTAX (562349/20103), REFLORA (563558/2010-5), PPBIO (558317/2009-0 e 457427/2012-4), e Fundação de Amparo à Pesquisa do Estado da Bahia (APR 0218/2008 e PNE 0020/2011). O presente trabalho foi realizado com apoio da Coordenação de Aperfeiçoamento de Pessoal de Nível Superior -Brasil (CAPES) - Código de Financiamento 001, com a concenssão de bolsa de Mestrado à primeira autora. Ao professor Abel Conceição pela fotografia de P. lanciflorum e disponibilização de material. Aos curadores e funcionários dos herbários consultados, pelo acesso às coleções, em especial a Teonildes Nunes e Elaine Miranda por toda a disposição e ajuda no HUEFS.

\section{REFERÊNCIAS}

Aliscioni, S. 2000. Anatomía ecológica de algumas espécies del género Paspalum (Poaceae, Panicoideae: Paniceae). Darwiniana 38: 187-207.

Allem, A.C. \& Valls, J.F.M. 1987. Recursos Forrageiros Nativos do Patanal Mato-Grossense. Empresa Brasileira de Pesquisa Agropecuária. Centro Nacional de Recursos Genéticos, Brasília, p. 94.

Andrade, P.M., Gontijo, T.A. \& Grandi, T.S.M. 1986. Composição florística e aspectos estruturais de uma área de "campo rupestre" do Morro do Chapéu, Nova Lima, Minas Gerais. Revista Brasileira de Botânica 9: 13-21.

Barreto, I.L. 1966. Las espécies afines a Paspalum quadrifarium (Gramineae) em La América Del Sur de clima sbtropical y templado. Darwiniana 14: 130-155.

Burman, S.G. 1985. The genus Thrasya H.B.K. (Graminae). Acta Botanica Venezuelana 14: 7-93.

Companhia de Desenvolvimento e Ação Regional - CAR. 1995. Chapada Diamantina: perfil regional. Salvador, Bahia, p.73.

Chase, A. 1929. The North American species of Paspalum. Contribution from the United States National Herbarium 28: 1-310.

Conceição, A.A. \& Giulietti, A.M. 2002. Composição florística e aspectos estruturais de campo rupestre em dois platôs do Morro do Pai Inácio, Chapada Diamantina, Bahia, Brasil. Hoehnea 29: 34-38.

Conceição, A.A. \& Pirani, J.R. 2005. Delimitação de hábitats em campos rupestres na Chapada Diamantina, Bahia: Substrato, composição florística e aspectos estruturais. Boletim de Botânica da Universidade de São Paulo 23: 85-111.

Conceição, A.A., Rapini, A., Pirani, J.R., Giulietti, A.M., Harley, R.M., Silva, T.R.S., Santos, A.K.A., Cosme, C., Andrade, I.M., Costa, J.A.S., Souza, L.R.S., Andrade, M.J.G., Funch, R.R., Freitas, T.A., Freitas, 
A.M.M. \& Oliveira, A.A. 2005. Campos Rupestres. In Biodiversidade e conservação da Chapada Diamantina. (F.A. Juncá, L.Funch \& W. Rocha, orgs.). Ministério do Meio Ambiente, Brasília, p. 153-180.

Denham, S.S. 2005. Revisión sistemática del subgênero Harpostachys de Paspalum (Poaceae: Panicoideae: Paniceae). Annals of the Missouri Botanical Garden 92: 463-532.

Denham, S.S., Zuloaga, F.O. \& Morrone, O. 2002. Systematic revision and phylogeny of Paspalum subgenus Ceresia (Poaceae: Panicoideae: Paniceae). Annals of the Missouri Botanical Garden 89: 337-399.

Drummond, G.M., Martins, C.S., Machado, A.B.M., Sebaio, F.A. \& Antonini, Y. (orgs). 2005. Biodiversidade em Minas Gerais: um atlas para sua conservação. Fundação Biodiversitas, Belo Horizonte, p 163-178.

Environmental Systems Research Institute - ESRI. 2010. ArcGIS, version 9.3.1. Redlands, CA: Environmental Systems Research Institute, Inc.

Flora do Brasil 2020 (em construção). Paspalum in Flora do Brasil 2020. Jardim Botânico do Rio de Janeiro. Disponível em: $<$ http:// floradobrasil.jbrj.gov.br/reflora/floradobrasil/FB13432>. Acesso em: 09 Abr. 2019.

Giulietti, A.M., Harley, R.M. \& Queiroz, L.P. 1996. Vegetação e flora da Chapada Diamantina, Bahia. In Anais da $4^{a}$ Reunião Especial da Sociedade Brasileira para o Progresso da Ciência - Universidade Estadual de Feira de Santana, p. 144-155.

Giulietti, A.M., Menezes, N.L., Pirani, J.R., Meguro, M. \& Wanderley, M.G.L. 1987. Flora da Serra do Cipó, minas Gerais: caracterização e lista das espécies. Boletim de Botânica da Universidade de São Paulo 9: 1-151.

Hackel, E. 1901. Neue Gräser. Österreichische Botanische Zeitschrift 51: 234.

Harley, R.M. 1995. Introdução. In Flora of the Pico das Almas Chapada Diamantina - Bahia, Brazil (B.L. Stannard, ed.). Royal Botanic Gardens Kew, Richmond, United Kingdom, p. 715-717.

Harley, R.M., Giulietti, A.M., Grilo, A.S., Silva, T.R.S., Funch, L., Funch, R.R., Queiroz, L.P., França, F., Melo, E., Gonçalver, C.N., Nascimento, F.H.F. 2005. Cerrado. In Biodiversidade e conservação da Chapada Diamantina (F.A. Juncá, L. Feunch e W. Rocha, orgs). Ministério do Meio Ambiente, Brasília, Brasil, p.121-152.

Maciel, J.R., Oliveira, R.C. \& Alves, M. 2009. Paspalum L. (Poaceae: Panicoideae: Paniceae) no estado de Pernambuco. Brasil. Acta Botanica Brasilica 23: 1145-1161.

Mori, S.A., Silva, L.A.M., Lisboa, G. \& Coradin, L. 1989. Manual de manejo do herbário fanerogâmico. Centro de Pesquisas do Cacau, Ilhéus, Bahia, Brasil, p. 1-104

Morrone, O., Aagesen, L., Scataglini, M.A., Salariato, D.L., Denham, S.S., Chemisquy, M.A., Sede, S.M., Giussani, L.M., Kellogg, E.A. \& Zuloaga, F.O. 2012. Phylogeny of the Paniceae (Poaceae: Panicoideae): integrating plastid DNA sequences and morphology into a new classification. Cladistics 28: 333-356.

Morrone, O., Denham, S.S. \& Zuloaga, F.O. 2004. Revisión taxonómica del género Paspalum grupo Eriantha (Poaceae, Panicoideae, Paniceae). Annals of the Missouri Botanical Garden 91: 225-246.

Oliveira, R.C. 2004. O gênero Paspalum L., grupo Plicatula (Poaceae: Paniceae), no Brasil. Tese. Universidade Estadual de Campinas, São Paulo.

Oliveira, R.C. \& Valls, J.F.M. 2001. Paspalum. In Flora Fanerogâmica do Estado de São Paulo - Poaceae (H.M. Longhi-Wagner, V. Bittrich, M.G.L. Wanderley \& G.J. Shepherd eds.). Hucitec, São Paulo, v.1, p 1-291.
Oliveira, R.C. \& Valls, J.F.M. 2002. Taxonomia de Paspalum L., grupo Linearia (Gramineae - Paniceae) do Brasil. Revista Brasileira de Botânica 25: 371-389.

Oliveira, R.C. \& Valls, J.F.M. 2008. Novos sinônimos e ocorrências em Paspalum L. (Poaceae). Hoehnea 35: 289-295.

Pimenta, K.M., Rua, G.H., Leite, K.R.B. \& Oliveira, R.P. 2013. Paspalum giuliettiae (Poaceae, Panicoideae), new grass from 'campos rupestres' of the Chapada Diamantina, Bahia, Brazil. Systematic Botany 38: 624-630.

Pirani, J.R., Mello-Silva, R. \& Giulietti, A.M. 2003. Flora de GrãoMogol, Minas Gerais, Brasil. Boletim de Botânica da Universidade de São Paulo 21: 1-24.

Rapini, A., Ribeiro, P.L., Lambert, S. \& Pirani, J.R. 2008. A flora dos campos rupestres da Cadeia do Espinhaço. Megadiversidade 4: 16-24.

Renvoize, S.A. 1984. The Grasses of Bahia. Royal Botanic Gardens Kew, Richmond, United Kingdom, p. 301.

Rocha, W.J.S., Chaves, J.M., Rocha, C.C. Funch, L. \& Juncá, F.A. 2005. Avaliação ecológica rápida da chapada Diamantina. In Biodiversidade e conservação da Chapada Diamantina (F.A., Juncá, L. Funch \& W. Rocha, orgs.). Ministério do Meio Ambiente, Brasília, p. 21-46.

Rua, G.H., Speranza, P., Vaio, M. \& Arakaki, M. 2010. A phylogenetic analysis of the genus Paspalum (Poaceae) based on cpDNA and morphology. Plant Systematic and Evolution 288: 227-243.

Sendulsky, T. \& Burman, A.G. 1978. Paspalum species of the Serra do Cipo (I): a contribution to the study of the Brazilian Poaceae. Revista Brasileira de Botânica 1: 1-15.

Sendulsky, T. \& Burman, A.G. 1980. A new species of Paspalum (Graminae) from Brazil. Brittonia 32: 487-489.

Silva, A.S. 2013. Delimitação taxonômica e variabilidade genetica de Paspalum polyphyllum Nees ex Trin. e Paspalum bicilium Mez (Poaceae, Paspaleae). Dissertação. Universidade de Brasília, Distrito Federal, p. 67.

Swallen, J.R. 1955. Flora of Guatemala: part II: grasses of Guatemala (P. Standley \& J.A. Steyermark, orgs). Fieldiana, Botany 24(2): 390.

Thiers, B. 2019. Index Herbariorum: a global directory of public herbaria and associated staff. New York Botanical Gardens's Virtual Herbarium. Disponível em: http://sweetgum.nybg.org/ih/ . Acessado em 12.04.20119

Trinius, C.B. 1826. Species graminum iconibus et descriptionibus illustravit. Petropoli 3: 360.

Viana, P.L. \& Filgueiras, T.S. 2008. Inventário e distribuição geográfica das gramíneas (Poaceae) na Cadeia do Espinhaço, Brasil. Megadiversidade 4: 72-78.

Vitta, F.A. 2002. Diversidade e conservação da flora nos campos rupestres da Cadeia do Espinhaço em Minas Gerais. In Biodiversidade, conservação e uso sustentável da flora do Brasil (E.L. Araújo, A.N. Moura, E.V.S.B. Sampaio, L.M.S. Gestinári \& J.M.T. Carneiro, eds.). Imprensa Universitária, Recife, p. 90-94

Zuloaga, F.O. \& Morrone, O. 2005. Revisión de las espécies de Paspalum para América del Sur Austral (Argentina, Bolívia, Sur de Brasil, Chile, Paraguay y Uruguay). Monographs in Systematic Botany from Missouri Botanical Garden 102: 1-297.

Zuloaga, F.O., Pensiero, J. \& Morrone, O. 2004. Systematics of Paspalum group Notata (Poaceae-Panicoideae-Paniceae). Systematic Botany Monographs 71: 1-75. 